\title{
Numerical modelling of steel plate girders at normal
}

\section{and elevated temperatures}

\author{
André Reis ${ }^{\mathrm{a}}$, Nuno Lopes ${ }^{\mathrm{a}}$, Esther Real ${ }^{\mathrm{b}}$, Paulo Vila Real ${ }^{\mathrm{a}}$ \\ ${ }^{a}$ RISCO - University of Aveiro, Department of Civil Engineering, Campus Universitário de Santiago, \\ 3810-193 Aveiro, Portugal; Telephone number. +351 234370942; Fax number +351 234370094 \\ ${ }^{\mathrm{b}}$ Department of Construction Engineering, Universitat Politècnica de Catalunya, UPC, 08034 Barcelona, \\ Spain
}

Keywords: Numerical validation, experimental tests, shear buckling, steel plate girders, fire.

\begin{abstract}
The main goal of this study is to increase the knowledge on the behaviour of steel plate girders subjected to shear buckling at both normal and elevated temperatures. Hence, numerical models were duly validated with experimental tests from the literature. Experimental tests on steel plate girders with different configurations were numerically reproduced, showing a good agreement between numerical and experimental results. Afterwards, applying the validated numerical models, sensitivity analyses on the influence of initial imperfections were performed. Different values for the maximum amplitude of geometric imperfections were considered and residual stresses were also taken into account. Finally, the effect of the end supports configuration was also studied aiming to understand the strength enhancement given by the rigid end support at normal temperature and evaluating if that strength enhancement is maintained in case of fire.
\end{abstract}




\section{Introduction}

Plate girders are widely used as structural members in steel construction because of their ability to support heavy loads over long spans. They are in general fabricated by welding together three steel plates corresponding to a web and two flanges. The web is designed to resist shear forces and the flanges to resist the applied bending moments. For economic reasons, plate girders have slender webs in order to have a high strength to weight ratio. These slender webs are highly susceptible to instability phenomena, particularly shear buckling. Therefore, it is common to design plate girders with transverse stiffeners and in some cases with longitudinal stiffeners in order to increase the buckling strength of the web plates.

Shear buckling is a type of local buckling caused by shear forces. Presently, the Rotated Stress Field Method [1] is the basis of the expressions adopted in European Standards, Part 1-5 of Eurocode 3 (EC3) [2], to check the ultimate shear resistance of steel plate girders subjected to shear buckling. In the last years, the accuracy of design methods at normal temperature have been analysed by different researchers, as for example Lee and Yoo [3-5], highlighting the shear buckling importance on the design of steel structures. However, it is still necessary to perform similar analyses for fire design.

Fire is an accidental action that may cause several damages in steel structures, as for example steel bridge structures, where the plate girders are often used. In fact, a research conducted by the New York Department of Transportation (NYDOT) found that 53 of the total recorded bridge failures up to 2011 are caused by fires and only 18 are caused by earthquakes [6]. Moreover, Kodur and Naser [7] stated that shear capacity can decrease faster than bending capacity meaning that the shear limiting state may be a dominant failure mode in steel plate girders subjected to fire. However, despite of the 
growing attention of the researchers on the behaviour of steel plate girders in fire situation, the accuracy of the application of the Rotated Stress Field Method to fire design has not yet been studied. For that reason, it is necessary to develop a solid numerical model to performing parametric studies in future works, in order to evaluate the applicability of the Rotated Stress Field Method to fire design.

Due to the limited size of furnaces and the high cost of the fire resistance experimental tests, several studies about fire resistance of steel structures have been performed in recent years based on numerical simulation [8]. However, it is still necessary to validate some of these numerical models to enable future parametric studies for the development of new analytical approaches very useful for designers that do not have always access to advanced calculation methods. Hence, a total of seventeen experimental tests $[9,10]$ at normal temperature carried out on steel plate girders were numerically reproduced, as well as nine experimental tests at elevated temperatures $[11,12]$. Comparisons between the experimental and the numerical results were performed. Afterwards, numerical sensitivity analyses at both normal and elevated temperatures were made in order to evaluate the influence of the geometric imperfections, the influence of the residual stresses and finally the influence of the end supports on the ultimate shear strength of steel plate girders, considering rigid and non-rigid end posts. These sensitivity analyses were performed based on the dimensions and material properties of the plate girders tested by Lee and Yoo [9]. Numerical modelling was conducted using the programme SAFIR [13,14], a computer software developed at University of Liege for the simulation of the behaviour of structures subjected to fire. 


\section{Review of experimental tests}

\subsection{Experimental tests at normal temperature}

In 1999, an experimental study of steel plate girders with non-rigid end posts was performed by Lee and Yoo [9], including the eight plate girders analysed in this paper. A shear dominant failure mode characterized by the web shear buckling was observed. The girders were simply supported and the load was applied at the mid-span. Figure 1 shows the geometry of the tested girders. The girders dimensions and the material properties are presented in Table 1 and Table 2 , respectively. The width of the transverse stiffeners is half of the flanges width and the horizontal dimension of the two small end panels is $300 \mathrm{~mm}$. All transverse stiffeners have $6 \mathrm{~mm}$ thickness with exception of those placed at the supports forming the non-rigid end post which have $10 \mathrm{~mm}$ thickness.

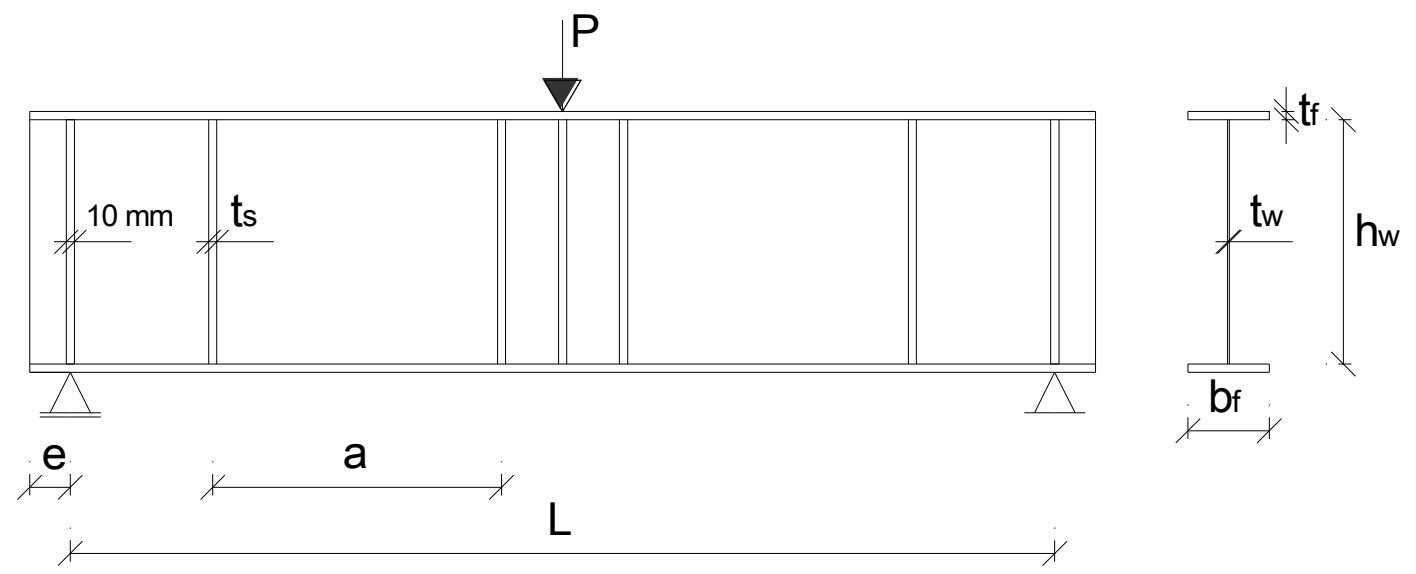

a) girders with $400 \mathrm{~mm}$ web depth (PG1 and PG4) 


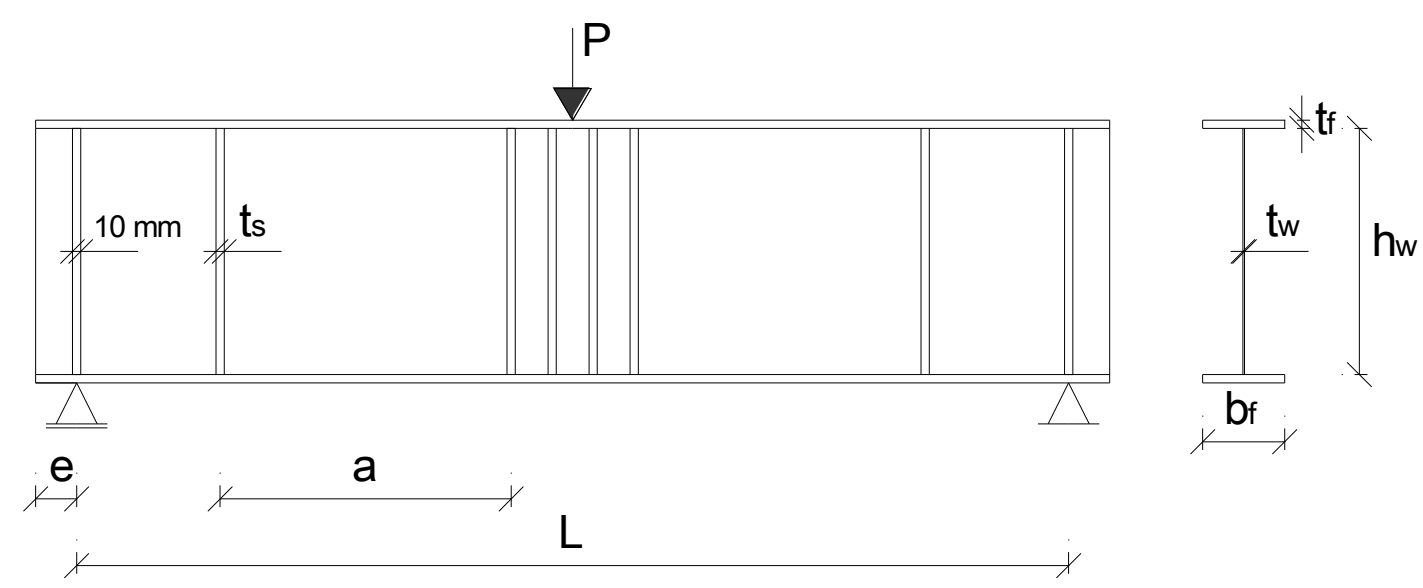

b) girders with $600 \mathrm{~mm}$ web depth (PG2, PG3 and PG5-8)

Figure 1 - Geometry of the plate girders tested by Lee and Yoo [9]

The experimental campaign performed at University of Minho by Gomes et al. [10] tested a total of six plate girders with non-rigid end posts divided into two series of three girders each. The girders from the first series only had transverse stiffeners, spaced by 300, 600 and $900 \mathrm{~mm}$ (see Figure 2). In the second series, a longitudinal stiffener was added to each girder tested in the first series. The longitudinal stiffener was placed $60 \mathrm{~mm}$ from the bottom surface of the upper flange. Table 1 shows the dimensions of the tested girders. The steel mechanical properties were obtained from tensile tests, using for this 18 samples from the 6 steel plates, 3 samples for each plate. The yield strength was $274 \mathrm{MPa}$ and the Young's modulus was $206 \mathrm{GPa}$, as shown in Table 2.

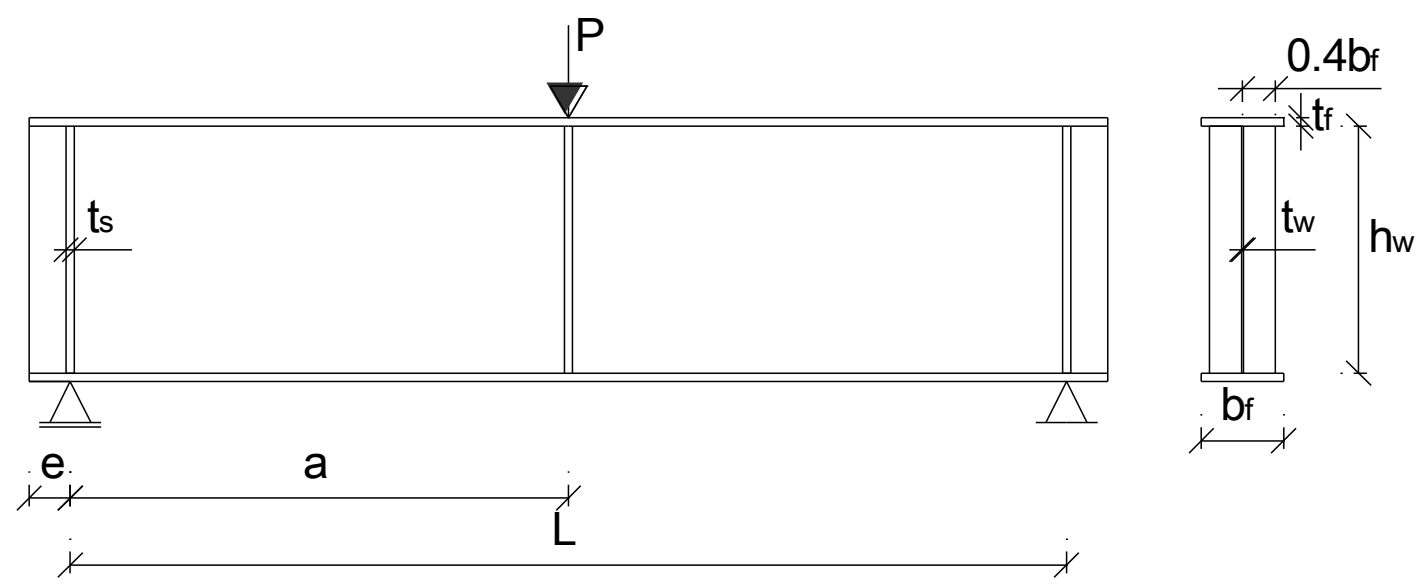

a) 

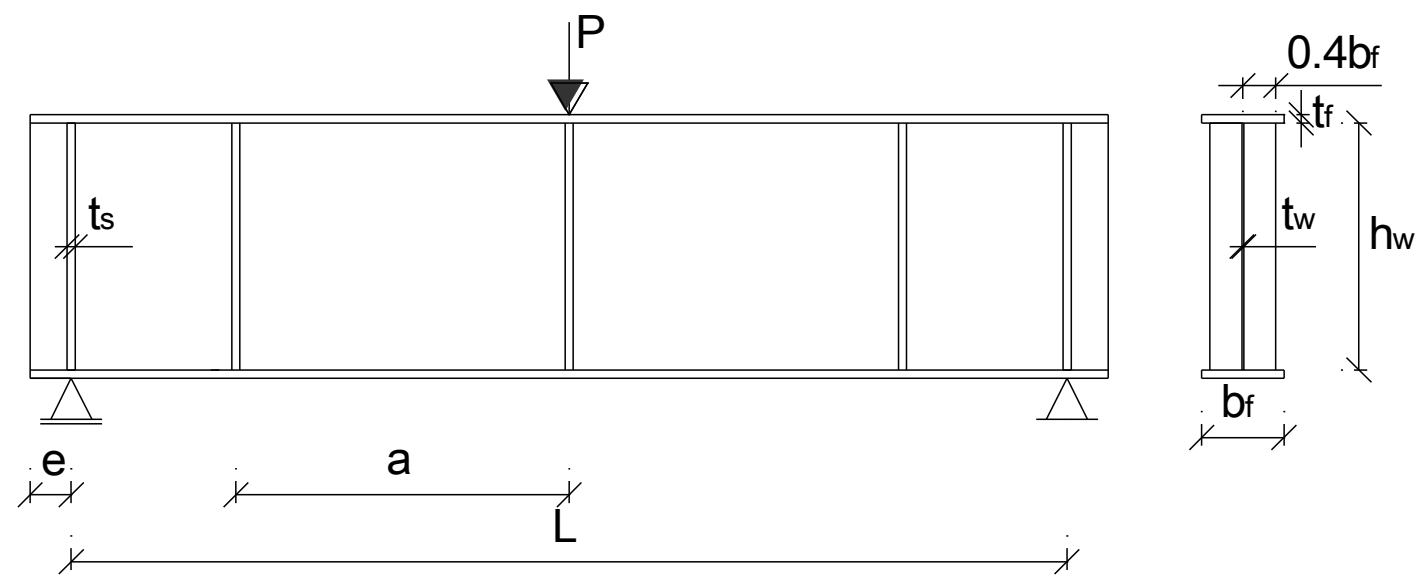

b)

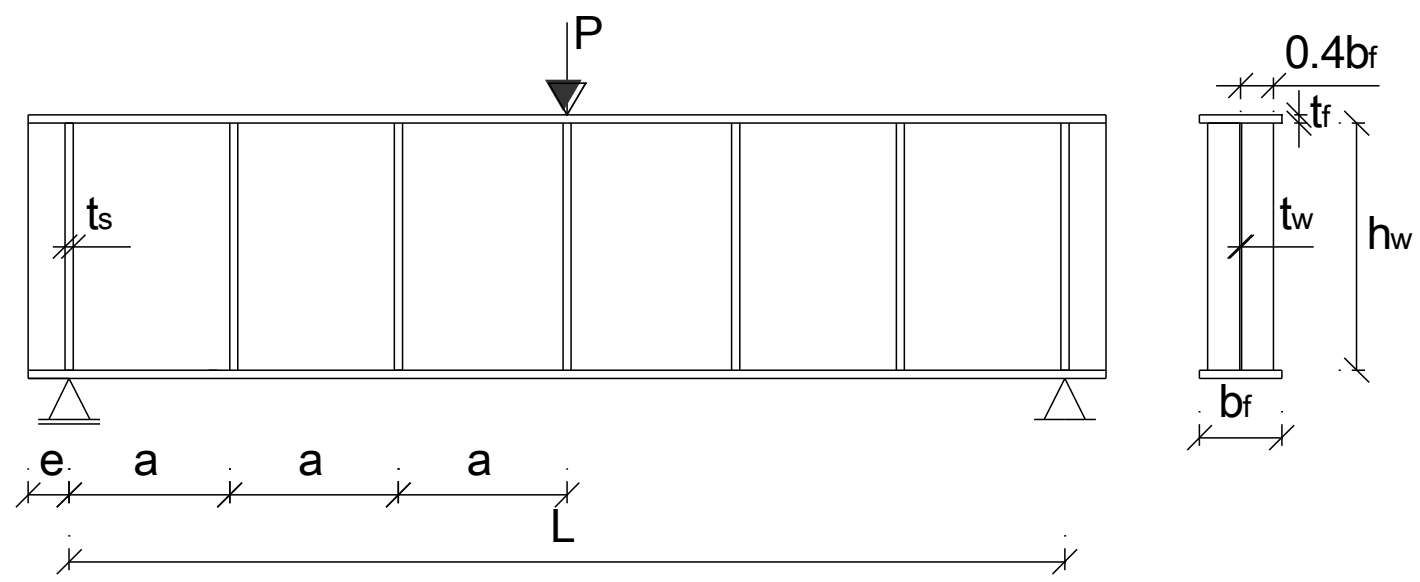

c)

Figure 2 - Geometry of the plate girders tested by Gomes et al. [10]

Table 1 - Dimensions of the plate girders tested at normal temperature

\begin{tabular}{|c|c|c|ccc|cc|cc|c|cc|c|}
\hline Label & Reference & $\begin{array}{c}\mathrm{T} \\
{\left[{ }^{\circ} \mathrm{C}\right]}\end{array}$ & $\begin{array}{c}\mathrm{L} \\
{[\mathrm{mm}]}\end{array}$ & $\begin{array}{c}\mathrm{a} \\
{[\mathrm{mm}]}\end{array}$ & $\begin{array}{c}\mathrm{e} \\
{[\mathrm{mm}]}\end{array}$ & $\begin{array}{c}\mathrm{h}_{\mathrm{w}} \\
{[\mathrm{mm}]}\end{array}$ & $\begin{array}{c}\mathrm{t}_{\mathrm{w}} \\
{[\mathrm{mm}]}\end{array}$ & $\begin{array}{c}\mathrm{b}_{\mathrm{f}} \\
{[\mathrm{mm}]}\end{array}$ & $\begin{array}{c}\mathrm{t}_{\mathrm{f}} \\
{[\mathrm{mm}]}\end{array}$ & $\begin{array}{c}\mathrm{t}_{\mathrm{s}} \\
{[\mathrm{mm}]}\end{array}$ & $\begin{array}{c}\mathrm{t}_{\mathrm{s}} \\
{[\mathrm{mm}]}\end{array}$ & $\begin{array}{c}\mathrm{b}_{\mathrm{ls}} \\
{[\mathrm{mm}]}\end{array}$ & $\begin{array}{c}\mathrm{a} / \mathrm{h}_{\mathrm{w}} \\
{[-]}\end{array}$ \\
\hline PG1 & & 20 & 1700 & 400 & 80 & 400 & 4.0 & 130 & 15.0 & 6.0 & - & - & 1.00 \\
PG2 & & 20 & 2100 & 600 & 100 & 600 & 4.0 & 200 & 10.0 & 6.0 & - & - & 1.00 \\
PG3 & & 20 & 2100 & 600 & 100 & 600 & 4.0 & 200 & 15.0 & 6.0 & - & - & 1.00 \\
PG4 & Lee and & 20 & 2100 & 600 & 80 & 400 & 4.0 & 130 & 15.0 & 6.0 & - & - & 1.50 \\
PG5 & Yoo [9] & 20 & 2700 & 900 & 100 & 600 & 4.0 & 200 & 10.0 & 6.0 & - & - & 1.50 \\
PG6 & & 20 & 2700 & 900 & 100 & 600 & 4.0 & 200 & 20.0 & 6.0 & - & - & 1.50 \\
PG7 & & 20 & 3300 & 1200 & 100 & 600 & 4.0 & 200 & 10.0 & 6.0 & - & - & 2.00 \\
PG8 & & 20 & 3300 & 1200 & 100 & 600 & 4.0 & 200 & 15.0 & 6.0 & - & - & 2.00 \\
\hline PG9 & & 20 & 1800 & 900 & 100 & 300 & 2.0 & 100 & 5.0 & 5.0 & - & - & 3.00 \\
PG10 & & 20 & 1800 & 600 & 100 & 300 & 2.0 & 100 & 5.0 & 5.0 & - & - & 2.00 \\
PG11 & Gomes et & 20 & 1800 & 300 & 100 & 300 & 2.0 & 100 & 5.0 & 5.0 & - & - & 1.00 \\
PG12 & al. [10] & 20 & 1800 & 900 & 100 & 300 & 2.0 & 100 & 5.0 & 5.0 & 5.0 & 50 & 3.00 \\
PG13 & & 20 & 1800 & 600 & 100 & 300 & 2.0 & 100 & 5.0 & 5.0 & 5.0 & 50 & 2.00 \\
PG14 & & 20 & 1800 & 300 & 100 & 300 & 2.0 & 100 & 5.0 & 5.0 & 5.0 & 50 & 1.00 \\
\hline
\end{tabular}


Table 2 - Material properties of the plate girders tested at normal temperature

\begin{tabular}{|c|c|cc|cc|cc|}
\hline Label & Reference & $\begin{array}{c}\mathrm{f}_{\mathrm{yw}} \\
{[\mathrm{MPa}]}\end{array}$ & $\begin{array}{c}\mathrm{E}_{\mathrm{w}} \\
\text { [GPa] }\end{array}$ & $\begin{array}{c}\mathrm{f}_{\mathrm{yf}} \\
{[\mathrm{MPa}]}\end{array}$ & $\begin{array}{c}\mathrm{E}_{\mathrm{f}} \\
{[\mathrm{GPa}]}\end{array}$ & $\begin{array}{c}\mathrm{f}_{\mathrm{ys}} \\
{[\mathrm{MPa}]}\end{array}$ & $\begin{array}{c}\mathrm{E}_{\mathrm{s}} \\
\text { [GPa] }\end{array}$ \\
\hline PG1 & & & & & & & \\
PG2 & & & & & & & \\
PG3 & & 318.5 & 210.0 & 303.8 & 210.0 & 318.5 & 210.0 \\
PG4 & Lee and & & & & & & \\
PG5 & Yoo [9] & & & & & & \\
PG6 & & & & & & & \\
PG7 & & & & & & & \\
PG8 & & 285.2 & 210.0 & 303.8 & 210.0 & 285.2 & 210.0 \\
\hline PG9 & & & & & & & \\
PG10 & & & & & & & \\
PG11 & Gomes et & 274.0 & 206.0 & 274.0 & 206.0 & 274.0 & 206.0 \\
PG12 & al. [10] & & & & & & \\
PG13 & & & & & & & \\
PG14 & & & & & & & \\
\hline
\end{tabular}

\subsection{Experimental tests at elevated temperature}

In 2007, an experimental campaign at normal and elevated temperature was carried out at Nanyang Technological University $[11,12]$. This was the first reported experimental work under fire conditions in the scope of shear buckling in steel plate girders. A total of 18 plate girders were tested, divided into five series. Beams with stocky hot-rolled cross-sections were tested in the two first series and for this reason they are not studied in this work. Only the last three series involving 12 plate girders with slender web panels that fail by shear are studied. The girders are simply supported and the load is applied at the mid-span. They were tested at elevated temperatures in electrical heating furnaces under steady-state conditions. The temperature was applied uniformly until the beam reached the specified temperature and after that the load was applied until the girder failure. The geometry of the tested girders is presented in Figure 3. The flange stiffener thickness is $12 \mathrm{~mm}$ and a same thickness for the transverse stiffeners was 
assumed. The dimensions and the material properties of the girders are presented in

Table 3 and

Table 4, respectively.
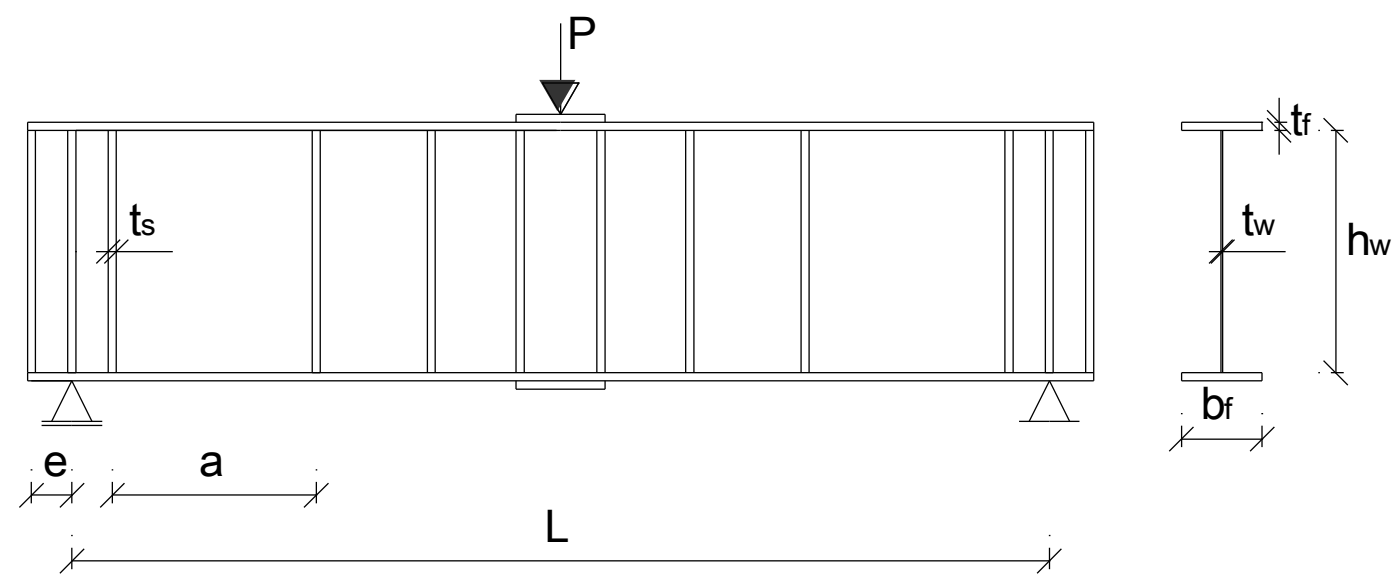

a) PG15-18
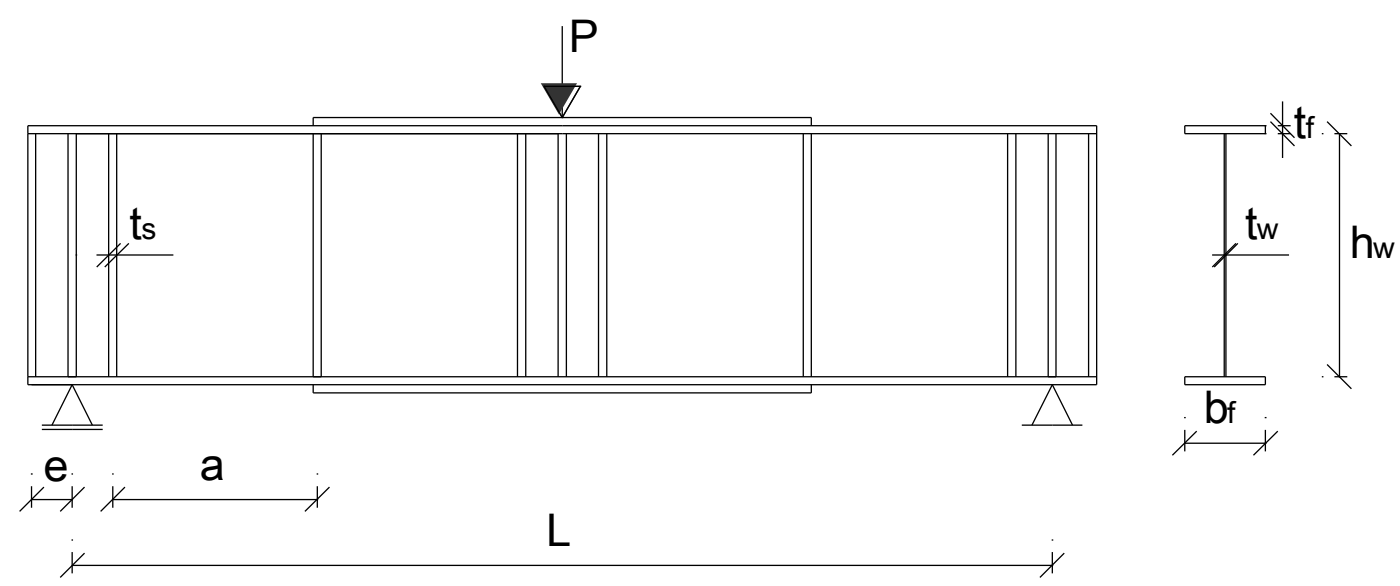

b) PG19-22

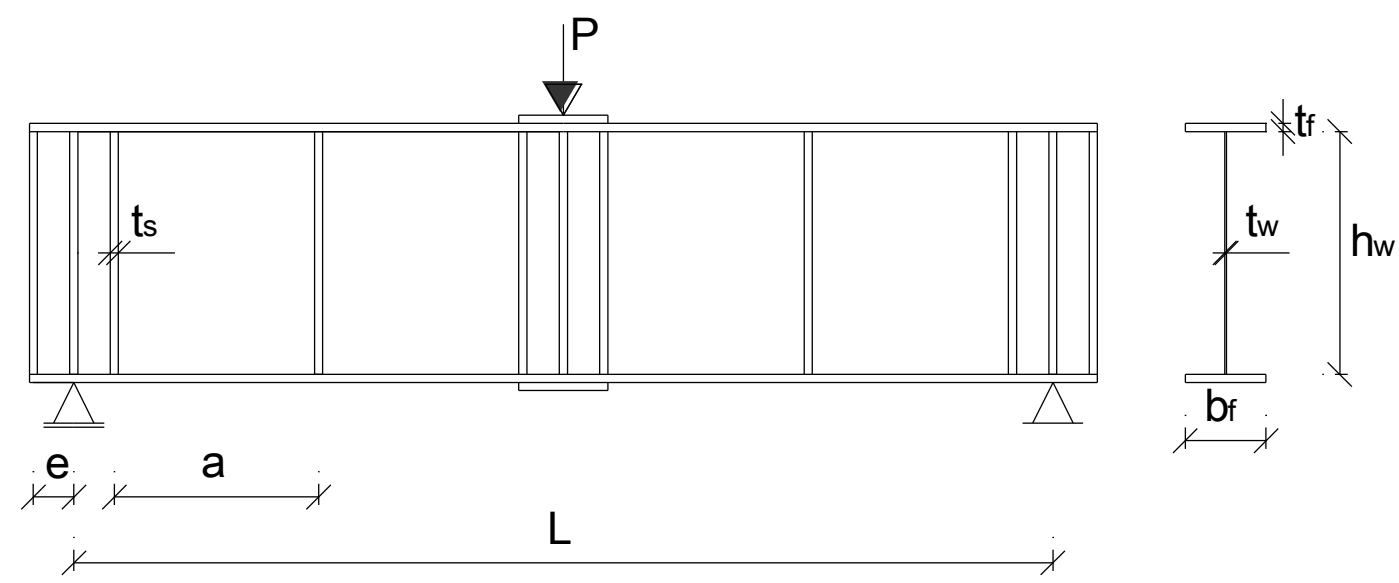

c) PG23-26 


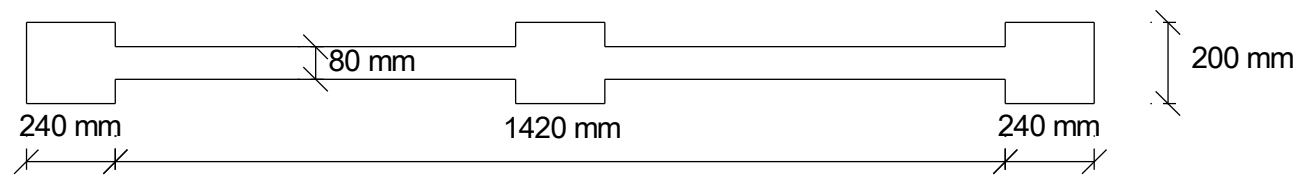

d) Plan view of the experimental test set-up

Figure 3 - Geometry of the plate girders tested at Nanyang Technological

University [11]

Table 3 - Dimensions of the plate girders tested at elevated temperatures

\begin{tabular}{|l|c|c|ccc|cc|cc|c|cc|c|}
\hline Label & Reference & $\begin{array}{c}\mathrm{T} \\
{\left[{ }^{\circ} \mathrm{C}\right]}\end{array}$ & $\begin{array}{c}\mathrm{L} \\
{[\mathrm{mm}]}\end{array}$ & $\begin{array}{c}\mathrm{a} \\
{[\mathrm{mm}]}\end{array}$ & $\begin{array}{c}\mathrm{e} \\
{[\mathrm{mm}]}\end{array}$ & $\begin{array}{c}\mathrm{h}_{\mathrm{w}} \\
{[\mathrm{mm}]}\end{array}$ & $\begin{array}{c}\mathrm{t}_{\mathrm{w}} \\
{[\mathrm{mm}]}\end{array}$ & $\begin{array}{c}\mathrm{b}_{\mathrm{f}} \\
{[\mathrm{mm}]}\end{array}$ & $\begin{array}{c}\mathrm{t}_{\mathrm{f}} \\
{[\mathrm{mm}]}\end{array}$ & $\begin{array}{c}\mathrm{t}_{\mathrm{s}} \\
{[\mathrm{mm}]}\end{array}$ & $\begin{array}{c}\mathrm{t}_{\mathrm{ls}} \\
{[\mathrm{mm}]}\end{array}$ & $\begin{array}{c}\mathrm{b}_{\mathrm{ls}} \\
{[\mathrm{mm}]}\end{array}$ & $\begin{array}{c}\mathrm{a} / \mathrm{h}_{\mathrm{w}} \\
{[-]}\end{array}$ \\
\hline PG15 & & 20 & 1660 & 305 & 120 & 305 & 2.0 & 80 & 6.0 & 12.0 & - & - & 1.00 \\
PG16 & & 400 & 1660 & 305 & 120 & 305 & 2.0 & 80 & 6.0 & 12.0 & - & - & 1.00 \\
PG17 & & 565 & 1660 & 305 & 120 & 305 & 2.0 & 80 & 6.0 & 12.0 & - & - & 1.00 \\
PG18 & & 690 & 1660 & 305 & 120 & 305 & 2.0 & 80 & 6.0 & 12.0 & - & - & 1.00 \\
PG19 & & 20 & 1660 & 305 & 120 & 305 & 2.7 & 80 & 6.0 & 12.0 & - & - & 1.00 \\
PG20 & Vimonsatit & 400 & 1660 & 305 & 120 & 305 & 2.7 & 80 & 6.0 & 12.0 & - & - & 1.00 \\
PG21 & et al. [11] & 550 & 1660 & 305 & 120 & 305 & 2.7 & 80 & 6.0 & 12.0 & - & - & 1.00 \\
PG22 & & 700 & 1660 & 305 & 120 & 305 & 2.7 & 80 & 6.0 & 12.0 & - & - & 1.00 \\
PG23 & & 20 & 1660 & 305 & 120 & 305 & 1.5 & 80 & 6.0 & 12.0 & - & - & 1.00 \\
PG24 & & 400 & 1660 & 305 & 120 & 305 & 1.5 & 80 & 6.0 & 12.0 & - & - & 1.00 \\
PG25 & & 550 & 1660 & 305 & 120 & 305 & 1.5 & 80 & 6.0 & 12.0 & - & - & 1.00 \\
PG26 & & 700 & 1660 & 305 & 120 & 305 & 1.5 & 80 & 6.0 & 12.0 & - & - & 1.00 \\
\hline
\end{tabular}

Table 4 - Material properties of the plate girders tested at elevated temperature

\begin{tabular}{|l|l|cc|cc|cc|}
\hline Label & Reference & $\begin{array}{c}\mathrm{f}_{\mathrm{yw}} \\
{[\mathrm{MPa}]}\end{array}$ & $\begin{array}{c}\mathrm{E}_{\mathrm{w}} \\
{[\mathrm{GPa}]}\end{array}$ & $\begin{array}{c}\mathrm{f}_{\mathrm{yf}} \\
{[\mathrm{MPa}]}\end{array}$ & $\begin{array}{c}\mathrm{E}_{\mathrm{f}} \\
{[\mathrm{GPa}]}\end{array}$ & $\begin{array}{c}\mathrm{f}_{\mathrm{ys}} \\
{[\mathrm{MPa}]}\end{array}$ & $\begin{array}{c}\mathrm{E}_{\mathrm{s}} \\
{[\mathrm{GPa}]}\end{array}$ \\
\hline PG15 & & & & & & & \\
PG16 & & 287.8 & 200.0 & 274.5 & 204.0 & 274.5 & 204.0 \\
PG17 & & & & & & & \\
PG18 & & & & & & & \\
PG19 & & & & & & & \\
PG20 & Vimonsatit & 232.8 & 200.0 & 277.0 & 204.0 & 277.0 & 204.0 \\
PG21 & et al. [11] & & & & & & \\
PG22 & & & & & & & \\
PG23 & & & & & & & \\
PG24 & & 332.0 & 200.0 & 277.0 & 204.0 & 277.0 & 204.0 \\
PG25 & & & & & & & \\
PG26 & & & & & & & \\
\hline
\end{tabular}




\section{FEM model}

The numerical modelling of the experimental tests was performed using SAFIR [13,14]. A 3D FEM-model was developed to perform geometrically and materially nonlinear numerical analyses including imperfections (GMNIA). Quadrangular shell elements with four integration nodes and four levels within the thickness were used in order to reproduce the local buckling phenomena typical from these slender cross sections. In the following sub-sections, the numerical model is presented in detail.

\subsection{Boundary conditions and loading}

The plate girders modelled in this work are simply supported. The boundary conditions are presented in Table 5 and illustrated in Figure 4. Lateral bracings in the upper flange were used to prevent lateral torsional buckling, as it can be seen in Figure 4. The loading was applied through the imposition of a concentrated load at mid-span, as executed in the experimental tests modelled in this study. In the numerical mode, this concentrated load is distributed on the entire web depth to avoid numerical problems.

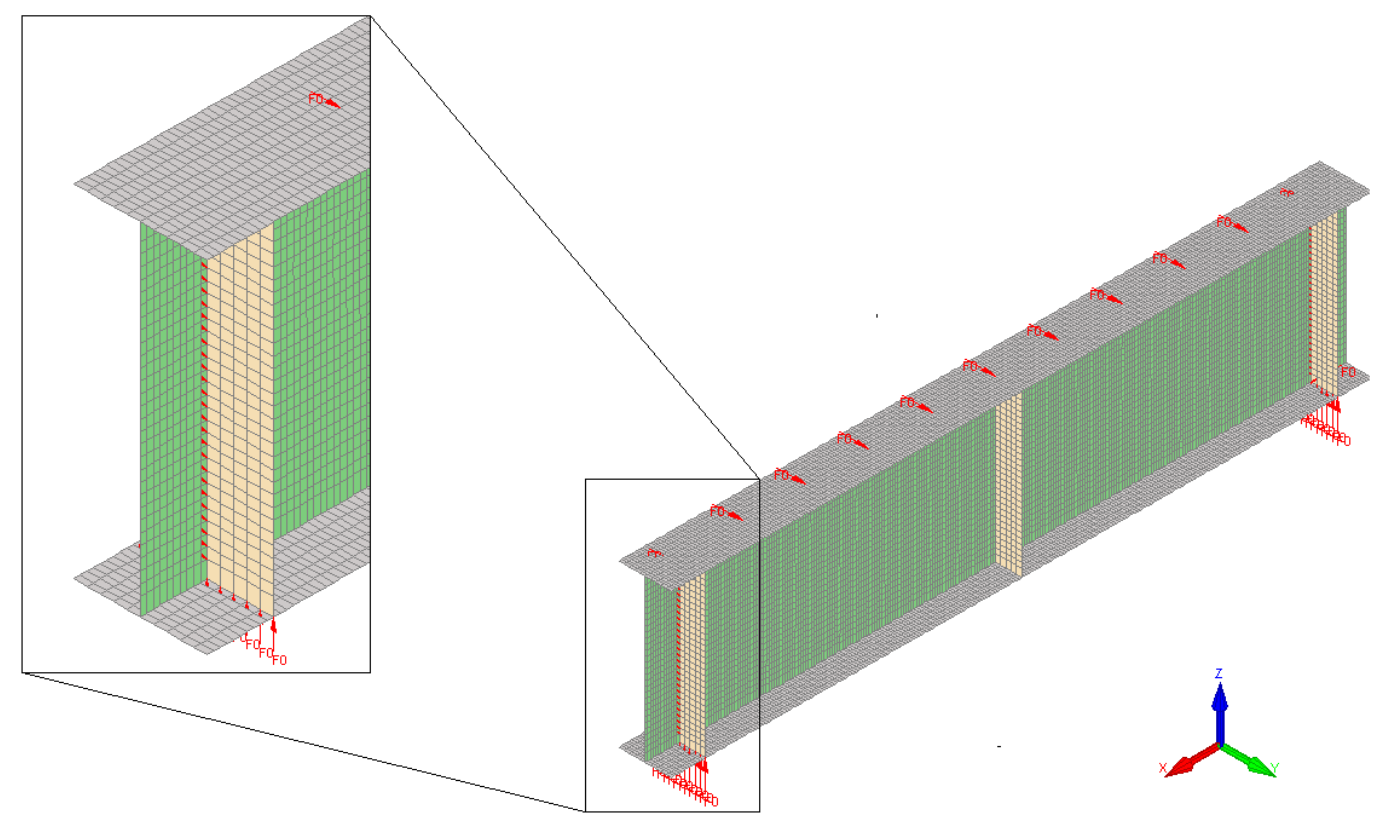

Figure 4 - Numerical model 
Table 5 - Boundary conditions (0-free, 1-fixed)

\begin{tabular}{|c|c|c|c|c|c|c|c|}
\hline \multicolumn{2}{|c|}{ Boundary } & $\Delta_{\mathrm{x}}$ & $\Delta_{\mathrm{y}}$ & $\Delta_{\mathrm{z}}$ & $\theta_{\mathrm{x}}$ & $\theta_{\mathrm{y}}$ & $\theta_{\mathrm{z}}$ \\
\hline \multirow{2}{*}{ Left support } & Web & 0 & 1 & 0 & 0 & 0 & 0 \\
& Lower flange & 0 & 0 & 1 & 0 & 0 & 0 \\
\hline \multirow{2}{*}{ Right support } & Web & 0 & 1 & 0 & 0 & 0 & 0 \\
& Lower flange & 1 & 0 & 1 & 0 & 0 & 0 \\
\hline Lateral bracings & Upper flange & 0 & 1 & 0 & 0 & 0 & 0 \\
\hline
\end{tabular}

\subsection{Mesh}

A sensitivity analysis was performed in order to find the necessary mesh refinement to obtain reliable results. The ultimate load was numerically obtained using SAFIR for a simply supported plate girder, considering different mesh refinements. The results are presented in Figure 5. A mesh refinement with 30 divisions in the web, 10 divisions in the flanges and 100 divisions per meter of beam length, which amounts to 5000 finite elements per meter of beam length, was considered adequate to accurately represent the beam behaviour, as marked with a circle in Figure 5 .

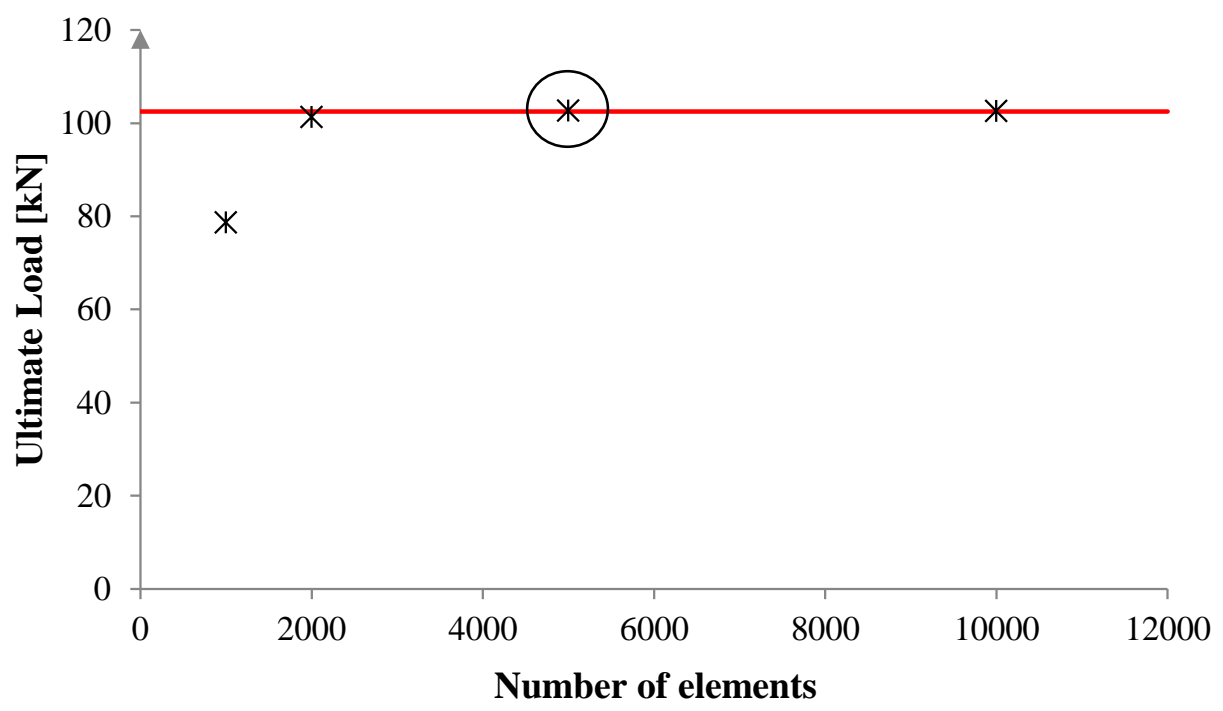

Figure 5 - Mesh sensitivity analysis 


\subsection{Geometric imperfections}

Initial geometric imperfections are present in all steel structural members and influence their bearing capacity. These imperfections are mainly due to the production and fabrication process. Therefore, it is necessary to take them into account in the numerical model. For this purpose, a linear eigenvalue buckling analysis is performed to determine the lowest relevant buckling mode. The obtained shape is considered as the geometric imperfection, with a chosen amplitude, and it is incorporated in the non-linear analysis. As the global buckling was restrained by the application of lateral bracings in the upper flange, only local imperfections were considered in the numerical analysis. The local buckling modes were obtained using the computer programme CAST3M [15]. The interface between CAST3M and SAFIR was assured by RUBY [16]. The maximum imperfection amplitude was considered equal to $t_{w} / 10$, as used in different studies of plate buckling at normal temperature [17] and at elevated temperature [18]. Figure 6 shows one of the considered buckling modes.

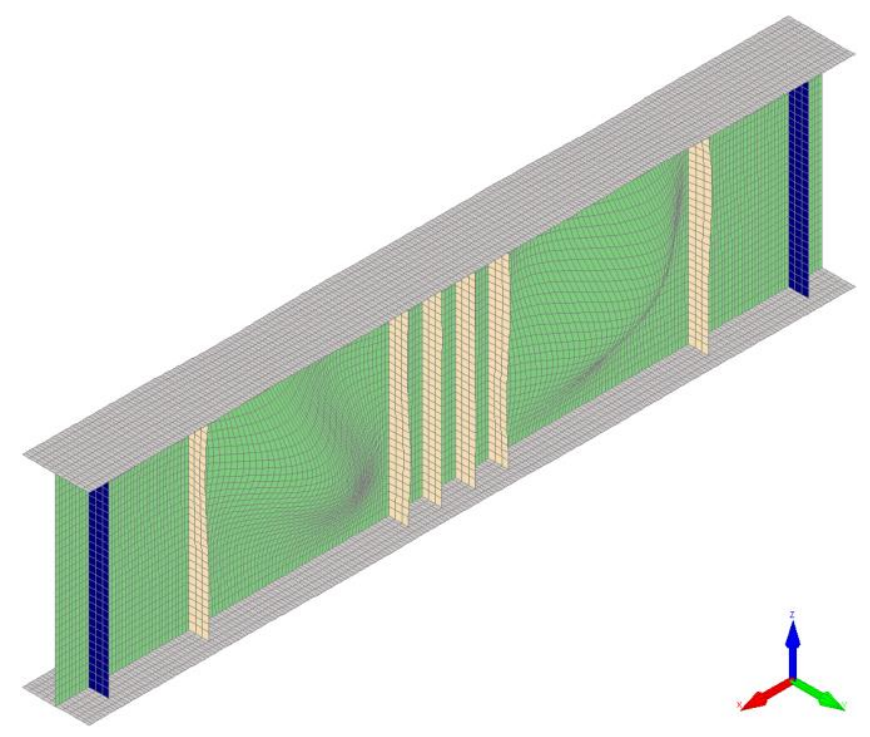

Figure 6 - Buckling mode of PG2 


\subsection{Material model}

The bi-linear material model with a yielding plateau was used in the analyses at normal temperature, according to Annex C of Part 1-5 of EC3 [2], and at elevated temperatures the steel stress-strain relationship defined in Part 1-2 of EC3 [19] was applied. Strainhardening was not taken into account in the steel material model for normal and elevated temperature. It is important to note that, these constitutive laws are compatible between each other, meaning that at $20^{\circ} \mathrm{C}$ they are the same. The parameters in Table 6 are the parameters involved on the determination of the steel stress-strain relationship in case of fire presented in Figure 7. At $20^{\circ} \mathrm{C} f_{p, \theta}$ is equal to $f_{y}$ resulting in $\varepsilon_{p, \theta}=\varepsilon_{y, \theta}$, which leads to not having the transition phase that follows the equation of an ellipse and having again an elastic-plastic law without strain hardening.

Table 6 - Expressions to determine the steel stress-strain relationship at elevated temperatures

\begin{tabular}{|c|c|c|}
\hline Strain range & Stress $\sigma$ & Tangent modulus \\
\hline$\varepsilon \leq \varepsilon_{p, \theta}$ & $E_{a, \theta} \varepsilon$ & $E_{a, \theta}$ \\
\hline$\varepsilon_{p, \theta}<\varepsilon<\varepsilon_{y, \theta}$ & $f_{p, \theta}-c+(b / a)\left[a^{2}-\left(\varepsilon_{y, \theta}-\varepsilon\right)^{2}\right]^{p .5}$ & $\frac{b\left(\varepsilon_{y, \theta}-\varepsilon\right)}{a\left[a^{2}-\left(\varepsilon_{y, \theta}-\varepsilon\right)^{2}\right]^{0.5}}$ \\
\hline$\varepsilon_{y, \theta} \leq \varepsilon \leq \varepsilon_{t, \theta}$ & $f_{y, \theta}$ & 0.00 \\
\hline$\varepsilon_{t, \theta}<\varepsilon<\varepsilon_{u, \theta}$ & $f_{y, \theta}\left[1-\left(\varepsilon-\varepsilon_{t, \theta}\right) /\left(\varepsilon_{u, \theta}-\varepsilon_{t, \theta}\right)\right]$ & - \\
\hline$\varepsilon=\varepsilon_{u, \theta}$ & 0.00 & - \\
\hline Parameters & $\varepsilon_{p, \theta}=f_{p, \theta} / E_{a, \theta}$ & $\varepsilon_{y, \theta}=0.02$ \\
\hline Additional functions are given in EN 1993-1-2
\end{tabular}




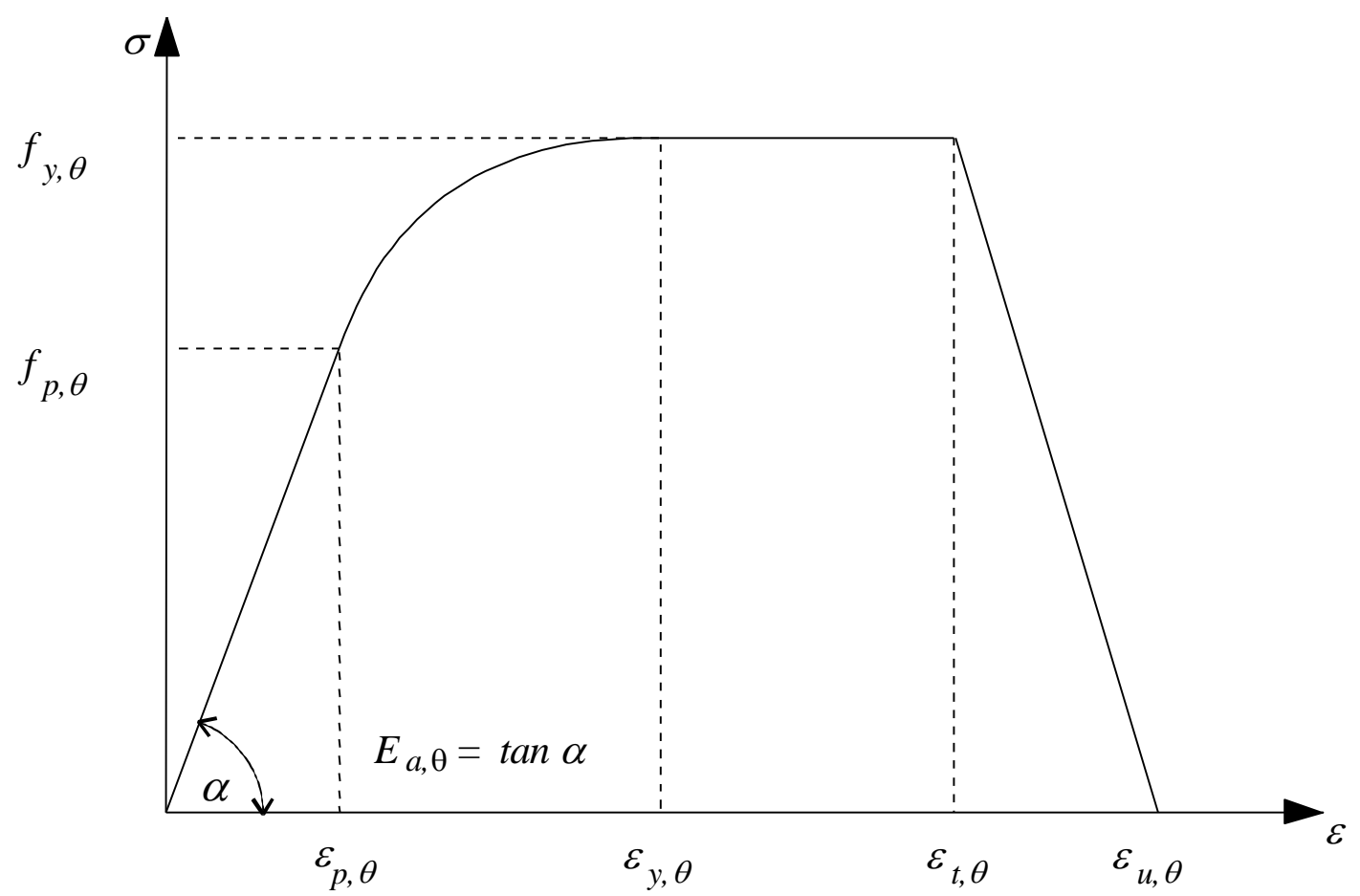

Figure 7 - Steel stress-strain relationship at elevated temperatures

\section{Comparisons between numerical and experimental results}

\subsection{Experimental tests and numerical simulations at normal temperature}

The steel plate girders experimentally tested at normal temperature by Lee and Yoo [9] were numerically modelled using the SAFIR software. The ultimate bearing capacity of the analysed plate girders is presented in Table 7, as well as the comparison between the numerical and the experimental results. It is shown that the plate girders ultimate load is well predicted by the numerical model developed in SAFIR. The mean deviation between the numerical and the experimental tests was $1.5 \%$. It was calculated in absolute. As it can be seen in Table 7 , the maximum conservative deviation was $2.8 \%$ and the maximum not conservative deviation was $1.7 \%$. 
Table 7 - Ultimate load of the steel plate girders tested by Lee and Yoo [9]

\begin{tabular}{|l|cc|c|}
\hline \multirow{2}{*}{ Label } & \multicolumn{2}{|c|}{ Ultimate load [kN] } & Deviation [\%] \\
& Exp. Tests (1) & SAFIR (2) & (2) vs (1) \\
\hline PG1 & 564.9 & 560.1 & -0.8 \\
PG2 & 664.9 & 662.6 & -0.3 \\
PG3 & 674.7 & 680.3 & 0.8 \\
PG4 & 537.6 & 523.0 & -2.7 \\
PG5 & 572.7 & 582.7 & 1.7 \\
PG6 & 625.7 & 609.2 & -2.6 \\
PG7 & 517.8 & 517.2 & -0.1 \\
PG8 & 552.9 & 537.5 & -2.8 \\
\hline
\end{tabular}

The out of plane web buckling observed in PG2 is illustrated in Figure 8. Figure 9 shows the web buckling at the end of the test of a plate girder with aspect ratio equal to 1.5 , whereas the web failure of a plate girder with aspect ratio equal to 2.0 is presented in Figure 10. As shown in these figures, the failure modes numerically obtained are quite similar to those observed in the experimental tests, particularly the web shear buckling and the formation of plastic hinges in the flanges.
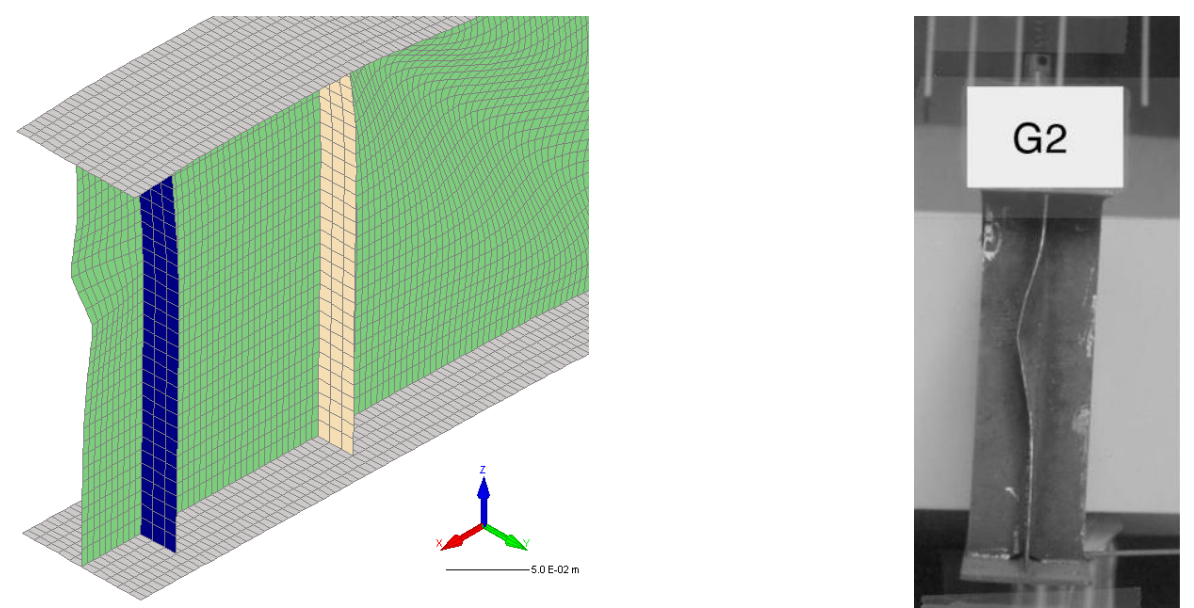

Figure 8 - Numerical and experimental [9] out of plane web buckling in the non-rigid end post of PG2 

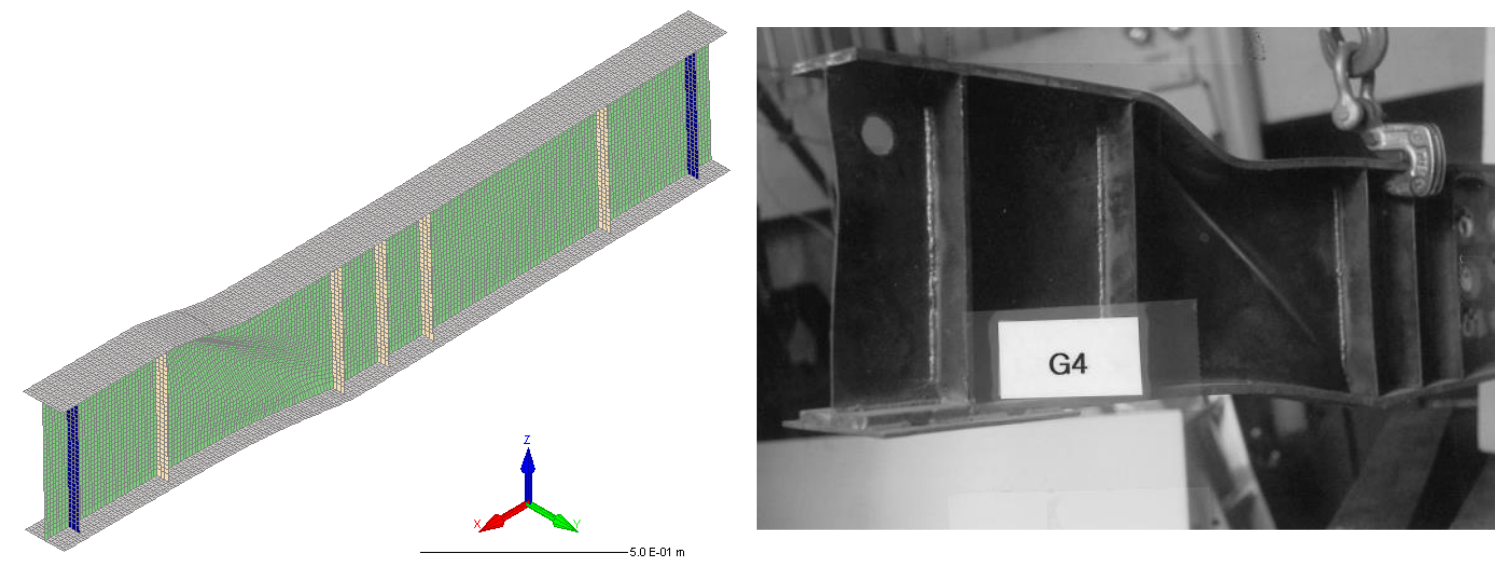

Figure 9 - PG4 numerical and experimental [9] deformed shape after test
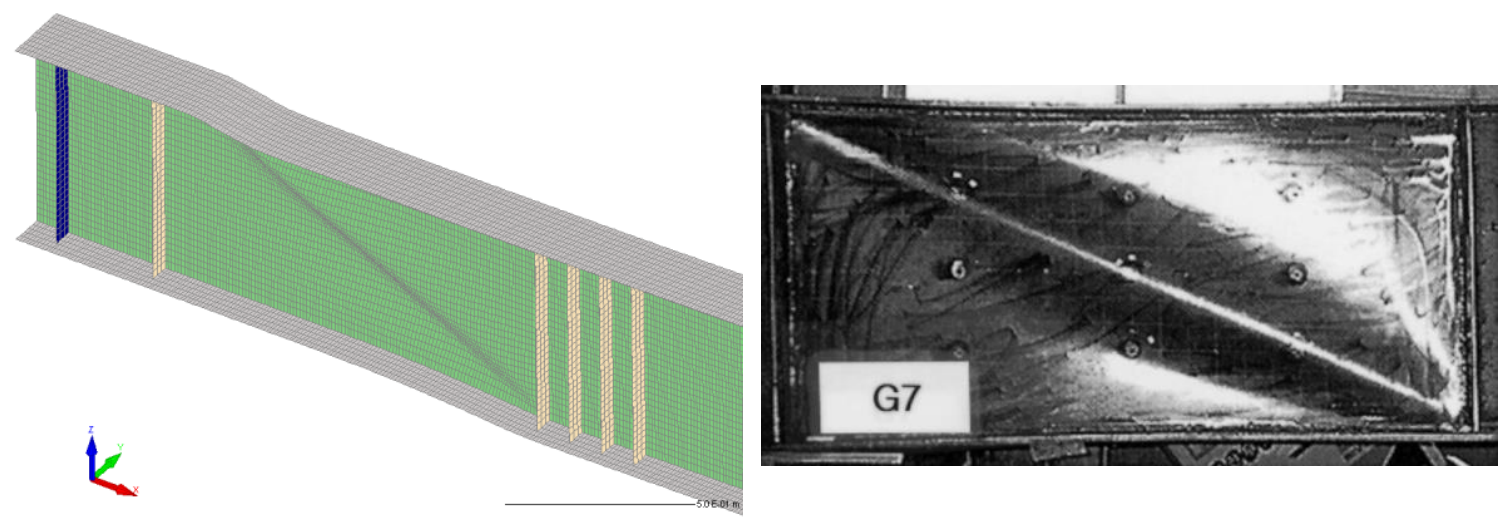

Figure 10 - PG7 numerical and experimental [9] deformed shape after test

The experimental tests performed by Gomes et al. [10] at University of Minho were numerically modelled using the SAFIR software. The experimental results obtained for the ultimate load are compared with those resulting from the numerical model (see Table 8). Through the comparison of results it is possible to observe that the numerical model provides a good aproximation to the actual behaviour of the tested girders, with a mean deviation in the ultimate load values equal to $4.1 \%$. The mean deviation was determined in absolute. Table 8 shows a maximum conservative deviation of $9.7 \%$ and a maximum not conservative deviation of $4.9 \%$. 
Table 8 - Ultimate load of the steel plate girders tested at University of Minho [10]

\begin{tabular}{|c|cc|c|}
\hline \multirow{2}{*}{ Label } & \multicolumn{2}{|c|}{ Ultimate load [kN] } & Deviation [\%] \\
& Exp. Tests (1) & SAFIR (2) & (2) vs (1) \\
\hline PG9 & 110.0 & 113.0 & 2.8 \\
PG10 & 110.0 & 115.4 & 4.9 \\
PG11 & 150.0 & 143.9 & -4.1 \\
PG12 & 130.0 & 132.0 & 1.5 \\
PG13 & 133.0 & 135.3 & 1.7 \\
PG14 & 172.0 & 155.4 & -9.7 \\
\hline
\end{tabular}

The comparison between the experimental ultimate load and the numerical ultimate load for all the steel plate girders test at normal temperature is presented in Figure 11. A good agreement between the experimental and the numerical results can be observed.

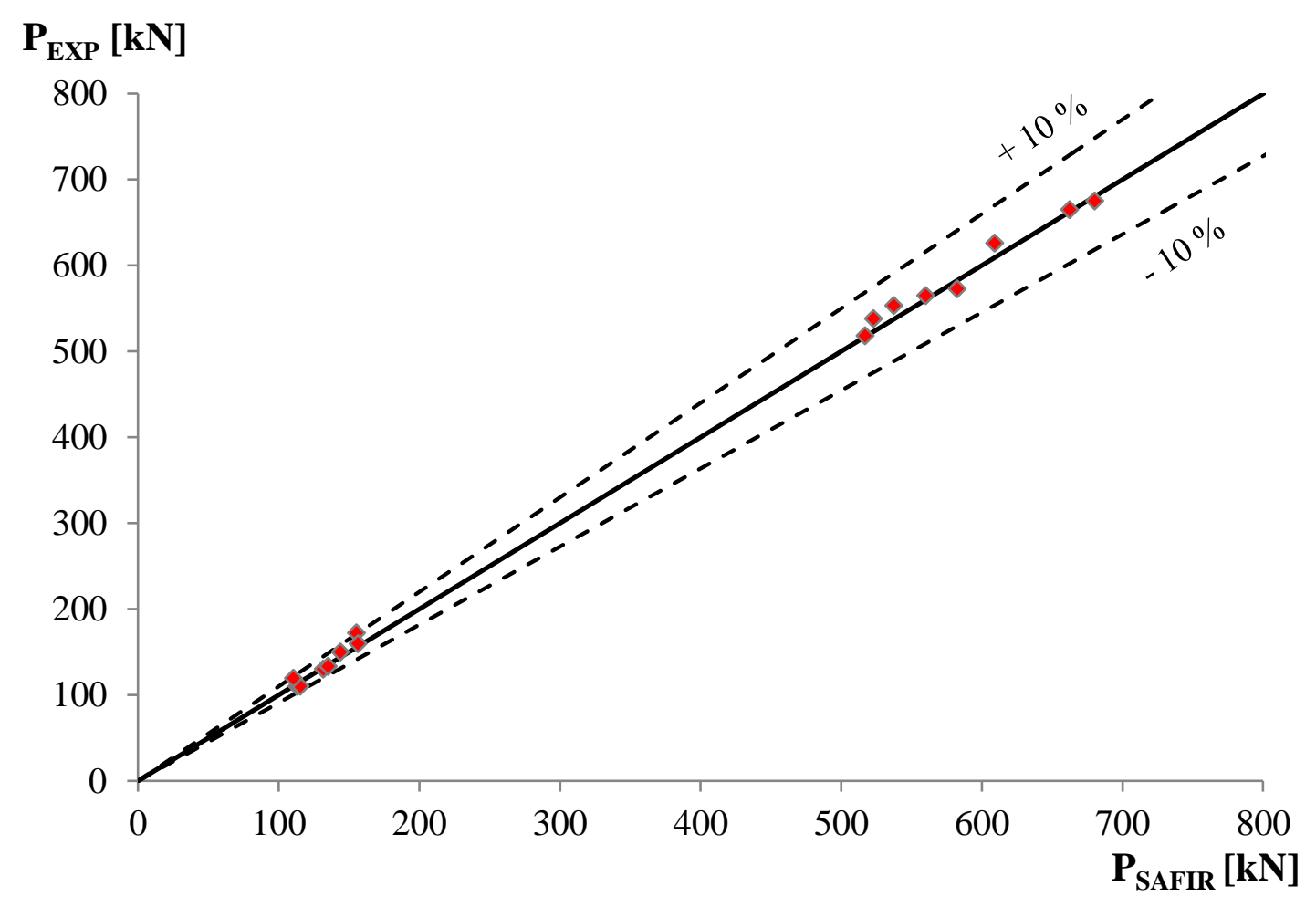

Figure 11 - Experimental and numerical ultimate shear strength of the analysed steel plate girders at normal temperature 


\subsection{Experimental tests and numerical simulations at elevated temperatures}

Elevated temperature experimental tests were conducted at Nanyang Technological University in Singapore. These tests were numerically reproduced by Vimonsatit et al. using the MARC software [20]. The ultimate loads of the overall test results are presented in Table 9, as well as a comparison between the numerical and the experimental results. A good agreement between the results of the numerical model developed in SAFIR and the experiments was obtained. From the results at normal temperature, a mean deviation between SAFIR and the experimental tests equal to $4.1 \%$ was observed, whereas the results obtained from MARC presented a $9.3 \%$ mean deviation when compared with the experimental tests. In the experimental tests at elevated temperatures, the authors in [11] noted that there was an error with the experimental setup of PG21. Consequently, the experimental results of this plate girder were not taken into account in the statistical analysis. Comparing the results at elevated temperatures, SAFIR presents a mean deviation of $8.4 \%$ when compared with the experimental tests, whereas a mean deviation equal to $10.9 \%$ was observed between MARC and the experiments. The numerical results obtained for PG20-22 present higher differences that were not observed in all of the other analysed plate girders. These girders have a flange stiffener over the web panel in order to force the girder to fail under web shear buckling and not flexure and its influence may be not considered in the right way by SAFIR. This fact is not very important because the application of flange stiffeners in plate girders is not a current practice in the steelwork construction. This way, if PG20-22 were not considered the mean deviation between the experimental and numerical results would decrease to $4.2 \%$. Therefore, it can be said that SAFIR provides 
results on the safety side agreeing well with the experiments. Figures 12 and 13 show the web buckling at elevated temperatures of some of the analysed plate girders.

Table 9 - Ultimate load of the steel plate girders tested at Nanyang Technological University

\begin{tabular}{|c|c|ccc|cc|}
\hline \multirow{2}{*}{ Label } & \multirow{2}{*}{ T $\left[{ }^{\circ} \mathrm{C}\right]$} & \multicolumn{3}{|c|}{ Ultimate load [kN] } & \multicolumn{2}{c|}{ Deviation [\%] } \\
& & Exp. Tests (1) & MARC (2) & SAFIR (3) & (2) vs (1) & (3) vs (1) \\
\hline PG15 & 20 & 159.7 & 176.0 & 156.6 & 10.2 & -2.0 \\
PG16 & 400 & 135.3 & 132.0 & 128.8 & -2.4 & -4.8 \\
PG17 & 565 & 68.7 & 76.8 & 74.6 & 11.8 & 8.6 \\
PG18 & 690 & 34.3 & 32.8 & 32.1 & -4.4 & -6.3 \\
PG19 & 20 & 223.6 & 224.0 & 230.6 & 0.2 & 3.1 \\
PG20 & 400 & 154.2 & 172.0 & 178.3 & 11.5 & 15.6 \\
PG21 & 550 & 75.5 & 104.2 & 111.8 & 38.0 & 48.1 \\
PG22 & 700 & 31.9 & 36.0 & 40.3 & 12.9 & 26.3 \\
PG23 & 20 & 119.2 & 140.0 & 110.6 & 17.4 & -7.2 \\
PG24 & 400 & 92.8 & 106.8 & 89.7 & 15.1 & -3.3 \\
PG25 & 550 & 57.2 & 65.0 & 56.3 & 13.6 & -1.5 \\
PG26 & 700 & 20.3 & 23.4 & 20.2 & 15.2 & -0.6 \\
\hline
\end{tabular}
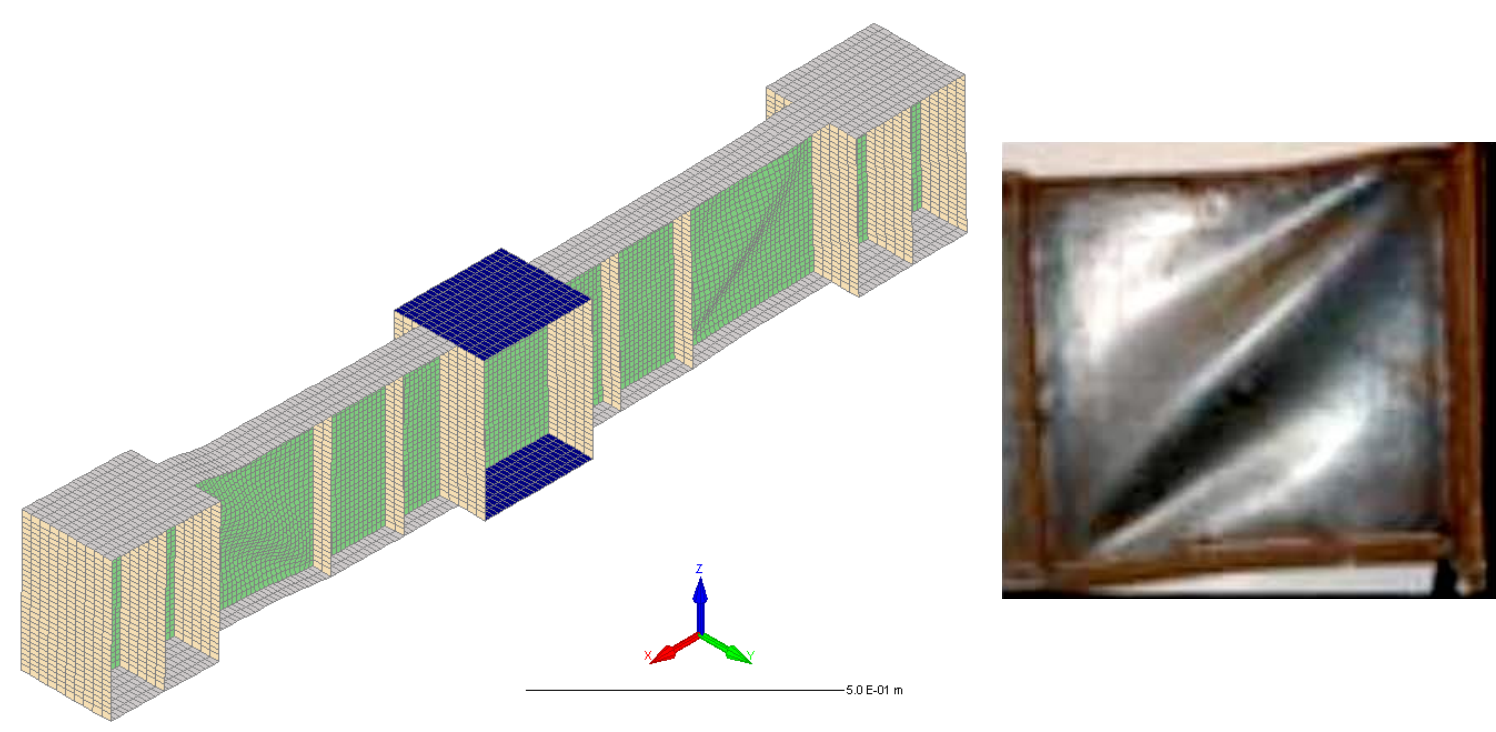

Figure 12 - PG16 numerical and experimental [11] deformed shape after test 

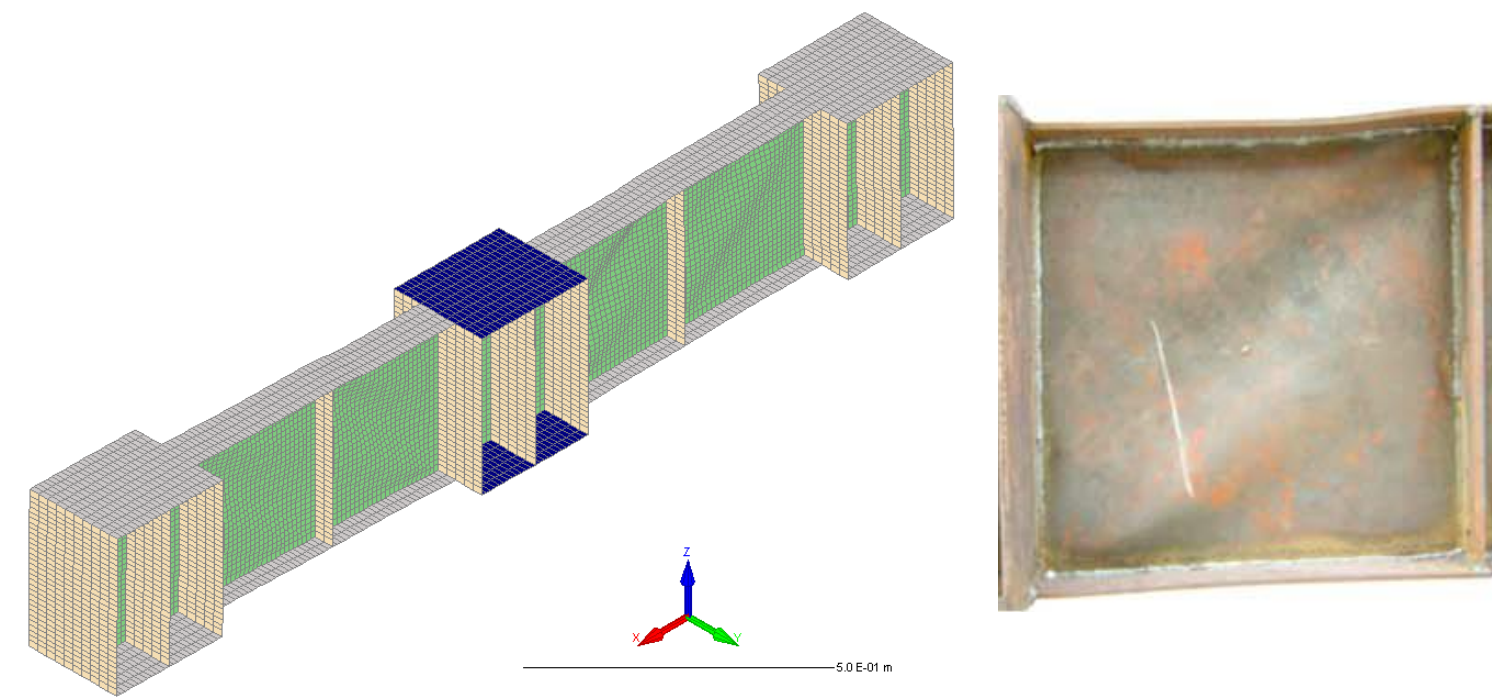

Figure 13 - PG25 numerical and experimental [11] deformed shape after test

Figure 14 presents the ultimate shear strength of the steel plate girders analysed at elevated temperatures. A good approximation between the experimental results and those obtained with SAFIR may be observed.

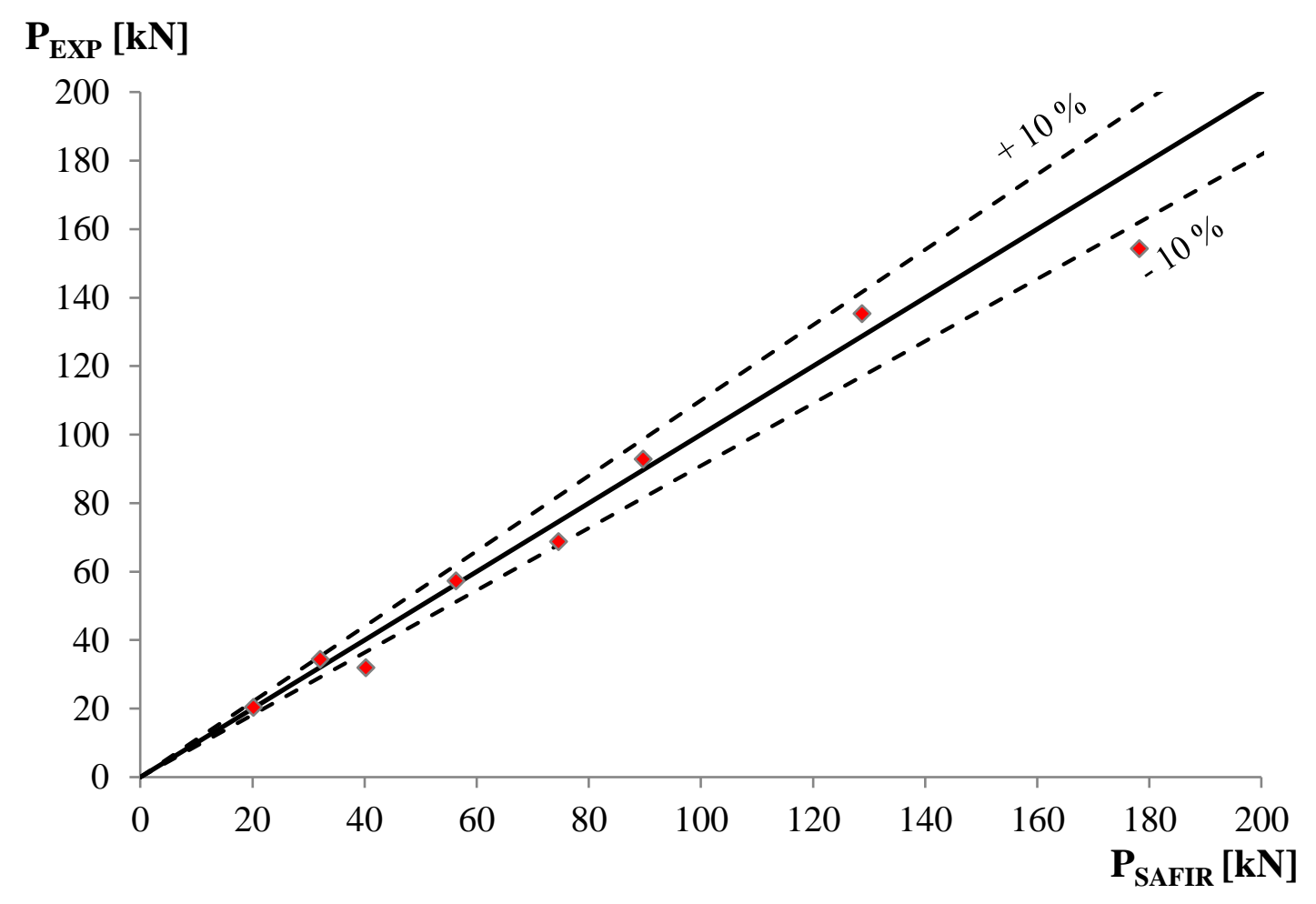

Figure 14 - Experimental and numerical ultimate shear strength of the analysed steel plate girders at elevated temperatures 


\section{Sensitivity analyses}

In this section, sensitivity analyses on the influence of the geometric imperfections, the residual stresses and the end supports on the ultimate shear strength of steel plate girders, at both normal and elevated temperatures, are presented. These sensitivity analyses were performed using the numerical model developed in SAFIR. The sensitivity analyses presented in this section were performed based on the steel plate girders tested by Lee and Yoo [9] whose dimensions and material properties were already presented in section 2.1 of this work. The sensitivity analyses at elevated temperature are performed using the same plate girders analysed at normal temperature. The plate girders were subjected to uniform temperatures equal to $350^{\circ} \mathrm{C}, 500^{\circ} \mathrm{C}$ and $600^{\circ} \mathrm{C}$ under steady-state conditions, i.e., the temperature is considered constant while the load is increased. As the conclusions are the same for all the analysed temperatures and due to space limitations, only the results at $500^{\circ} \mathrm{C}$ are presented in sections 5.2 and 5.3 .

\subsection{Geometric imperfections}

Different maximum amplitudes of the geometric imperfections were considered based on the web thickness $\left(100 \%, 50 \%, 10 \%\right.$ and $1 \%$ of $\left.\mathrm{t}_{\mathrm{w}}\right)$, including the value $\mathrm{t}_{\mathrm{w}} / 10$ recommended in other studies $[17,18]$, as well as the maximum amplitude recommended in EC3. Part 1-5 of EC3 [2], i.e., 80\% of the essential manufacturing tolerances, which can be found in EN 1090-2 [21]. Thus, the EC3 maximum amplitude corresponds to $0.8 \mathrm{~h}_{\mathrm{w}} / 100$ in the web and $0.8 \mathrm{~b}_{\mathrm{f}} / 100$ in the flanges. 


\subsubsection{Normal temperature}

The results of the geometric imperfections sensitivity analysis carried out on steel plate girders at normal temperature are presented in Table 10, listed from highest to lowest maximum amplitude. As expected, the higher the maximum amplitude is, the more conservative the results are. Comparing numerical and experimental results, the mean deviation is $4.6 \%$ on safe side when the maximum amplitude recommended in EC3 is used. When the maximum amplitude is taken as $10 \%$ of the web thickness the mean deviation is $0.9 \%$ on the safe side, which is the value that best fits the experimental results. Finally, considering a maximum amplitude equal to $1 \%$ of the web thickness is too soft, being the mean deviation $1.2 \%$ on the unsafe side, i.e. the ultimate loads numerically obtained are generally higher than those observed in the experimental tests. Furthermore, the consideration of the maximum amplitude recommended in EC3 is too severe for the numerical modelling of experimental tests, being $t_{w} / 10$ an appropriate value to use for that purpose.

Table 10 - Geometric imperfections sensitivity analysis at normal temperature

\begin{tabular}{|c|c|c|c|c|c|c|c|c|c|c|c|c|}
\hline \multirow{2}{*}{\multicolumn{3}{|c|}{ Exp. test }} & \multicolumn{10}{|c|}{ Maximum amplitude of the geometric imperfections } \\
\hline & & & \multicolumn{2}{|c|}{$t_{w}$} & \multicolumn{2}{|c|}{$\mathrm{EC} 3$} & \multicolumn{2}{|c|}{$\mathrm{t}_{\mathrm{w}} / 2$} & \multicolumn{2}{|c|}{$\mathrm{t}_{\mathrm{w}} / 10$} & \multicolumn{2}{|c|}{$\mathrm{t}_{\mathrm{w}} / 100$} \\
\hline Label & $\mathrm{a} / \mathrm{h}_{\mathrm{w}}$ & $\begin{array}{c}\mathrm{P} \\
{[\mathrm{kN}]}\end{array}$ & $\begin{array}{c}\mathrm{P} \\
{[\mathrm{kN}]}\end{array}$ & $\begin{array}{c}\text { Dev. } \\
{[\%]}\end{array}$ & $\begin{array}{c}\mathrm{P} \\
{[\mathrm{kN}]}\end{array}$ & $\begin{array}{c}\text { Dev. } \\
{[\%]}\end{array}$ & $\begin{array}{c}\mathrm{P} \\
{[\mathrm{kN}]}\end{array}$ & $\begin{array}{c}\text { Dev. } \\
{[\%]}\end{array}$ & $\begin{array}{c}\mathrm{P} \\
{[\mathrm{kN}]}\end{array}$ & $\begin{array}{c}\text { Dev. } \\
{[\%]}\end{array}$ & $\begin{array}{c}\mathrm{P} \\
{[\mathrm{kN}]}\end{array}$ & $\begin{array}{c}\text { Dev. } \\
{[\%]}\end{array}$ \\
\hline PG1 & 1.00 & 564.9 & 515.7 & -8.7 & 518.0 & -8.3 & 527.3 & -6.6 & 560.1 & -0.8 & 585.5 & 3.7 \\
\hline PG2 & 1.00 & 664.9 & 652.9 & -1.8 & 651.8 & -2.0 & 654.7 & -1.5 & 662.6 & -0.3 & 665.2 & 0.0 \\
\hline PG3 & 1.00 & 674.7 & 670.0 & -0.7 & 669.2 & -0.8 & 672.1 & -0.4 & 680.3 & 0.8 & 682.9 & 1.2 \\
\hline PG4 & 1.50 & 537.6 & 468.6 & -12.9 & 475.5 & -11.6 & 489.5 & -9.0 & 523.0 & -2.7 & 558.4 & 3.9 \\
\hline PG5 & 1.50 & 572.7 & 564.2 & -1.5 & 561.0 & -2.0 & 574.0 & 0.2 & 582.7 & 1.7 & 584.7 & 2.1 \\
\hline PG6 & 1.50 & 625.7 & 591.1 & -5.5 & 590.9 & -5.6 & 598.8 & -4.3 & 609.2 & -2.6 & 610.7 & -2.4 \\
\hline PG7 & 2.00 & 517.8 & 512.9 & -1.0 & 510.1 & -1.5 & 520.0 & 0.4 & 517.2 & -0.1 & 527.4 & 1.9 \\
\hline PG8 & 2.00 & 552.9 & 528.9 & -4.3 & 524.8 & -5.1 & 539.1 & -2.5 & 537.5 & -2.8 & 549.2 & -0.7 \\
\hline \multicolumn{3}{|c|}{ Mean deviation [\%] } & & -4.6 & & -4.6 & & -3.0 & & -0.9 & & 1.2 \\
\hline
\end{tabular}




\subsubsection{Elevated temperature}

Table 11 shows the results of the influence of the geometric imperfections on steel plate girders under fire conditions. It was found that considering geometric imperfections causes a significant reduction on the ultimate shear strength and not considering them conducts to unrealistic shear buckling resistances. However, the maximum amplitude of the geometric imperfections has no significant influence on the ultimate capacity of the analysed plate girders. The mean deviation is equal to $0.6 \%$ for all the analysed temperatures. It would probably be much more important for girders exhibiting a bending dominant failure and even more relevant for girders affected by global buckling.

Table 11 - Geometric imperfections sensitivity analysis at elevated temperature

\begin{tabular}{|c|c|c|c|c|c|c|c|c|c|c|}
\hline \multirow[b]{2}{*}{ Label } & \multirow[b]{2}{*}{$\mathrm{a} / \mathrm{h}_{\mathrm{w}}$} & \multicolumn{3}{|c|}{$350^{\circ} \mathrm{C}$} & \multicolumn{3}{|c|}{$500^{\circ} \mathrm{C}$} & \multicolumn{3}{|c|}{$600^{\circ} \mathrm{C}$} \\
\hline & & $\begin{array}{l}\mathrm{tw} / 10 \\
\mathrm{P}[\mathrm{kN}]\end{array}$ & $\begin{array}{c}\mathrm{EC} 3 \\
\mathrm{P}[\mathrm{kN}]\end{array}$ & $\begin{array}{l}\text { Dev. } \\
\text { [\%] }\end{array}$ & $\begin{array}{l}\mathrm{tw} / 10 \\
\mathrm{P}[\mathrm{kN}]\end{array}$ & $\begin{array}{c}\mathrm{EC} 3 \\
\mathrm{P}[\mathrm{kN}]\end{array}$ & $\begin{array}{l}\text { Dev. } \\
\text { [\%] }\end{array}$ & $\begin{array}{l}\mathrm{tw} / 10 \\
\mathrm{P}[\mathrm{kN}]\end{array}$ & $\begin{array}{c}\mathrm{EC} 3 \\
\mathrm{P}[\mathrm{kN}]\end{array}$ & $\begin{array}{l}\text { Dev. } \\
{[\%]}\end{array}$ \\
\hline PG1 & 1.00 & 450.0 & 451.8 & 0.4 & 349.1 & 350.4 & 0.4 & 207.1 & 207.9 & 0.4 \\
\hline PG2 & 1.00 & 529.5 & 531.0 & 0.3 & 409.4 & 410.7 & 0.3 & 241.2 & 242.1 & 0.4 \\
\hline PG3 & 1.00 & 568.9 & 571.0 & 0.4 & 441.2 & 443.0 & 0.4 & 260.9 & 262.0 & 0.4 \\
\hline PG4 & 1.50 & 375.2 & 375.9 & 0.2 & 290.3 & 290.5 & 0.1 & 170.9 & 171.2 & 0.2 \\
\hline PG5 & 1.50 & 438.5 & 440.8 & 0.5 & 337.8 & 339.6 & 0.5 & 197.5 & 198.5 & 0.5 \\
\hline PG6 & 1.50 & 503.4 & 505.9 & 0.5 & 390.1 & 392.1 & 0.5 & 229.7 & 231.1 & 0.6 \\
\hline PG7 & 2.00 & 364.0 & 368.3 & 1.2 & 278.8 & 282.0 & 1.1 & 161.5 & 163.3 & 1.2 \\
\hline PG8 & 2.00 & 382.5 & 388.9 & 1.7 & 294.7 & 299.5 & 1.6 & 172.1 & 174.7 & 1.5 \\
\hline \multicolumn{2}{|c|}{ Mean deviation [\%] } & & & 0.6 & & & 0.6 & & & 0.6 \\
\hline
\end{tabular}

\subsection{Residual stresses}

The authors of the experimental tests did not measured the residual stresses and therefore, they were not taken into account in the numerical modelling presented in section 4 of this work. However, in this section their influence in the ultimate shear strength of steel plate girders is evaluated. For taking the residual stresses into account, SAFIR transform them into residual strains and add them to the other strains in the first 
calculation $[22,23]$. The pattern of residual stresses considered was the one proposed for welded I-sections, as shown in Figure 15 [24,25].

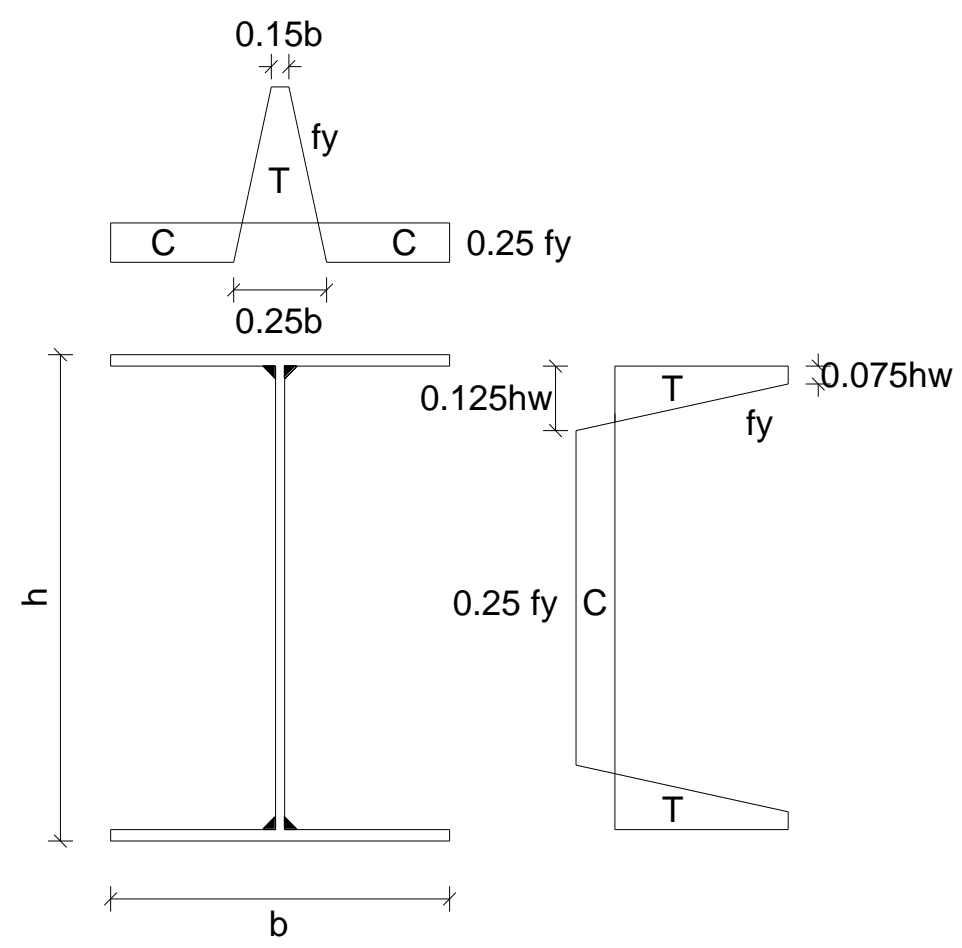

Figure 15 - Pattern of residual stresses for welded I-sections

\subsubsection{Normal temperature}

Table 12 presents the results of the numerical analysis about the influence of the residual stresses on the ultimate shear strength of steel plate girders at normal temperature. One may observe that the influence of the residual stresses is high, with the ultimate loads of the analysed girders on average $8.6 \%$ lower when a maximum amplitude of the geometric imperfections equal to $t_{w} / 10$ is used. When a higher geometric imperfections maximum amplitude is taken into account, like the one recommended by EC3, the reduction on the ultimate loads is not so high being on average $5.3 \%$. 
Table 12 - Residual stresses sensitivity analysis at normal temperature

\begin{tabular}{|c|c|c|c|c|c|c|c|}
\hline \multirow{3}{*}{ Label } & \multirow{3}{*}{$\mathrm{a} / \mathrm{hw}$} & \multicolumn{2}{|c|}{ Without Residual Stresses } & \multicolumn{4}{|c|}{ With Imperfections + Residual Stresses } \\
\hline & & $\mathrm{tw} / 10$ & EC3 & \multicolumn{2}{|c|}{$\mathrm{tw} / 10$} & \multicolumn{2}{|c|}{ EC3 } \\
\hline & & $\mathrm{P}[\mathrm{kN}]$ & $\mathrm{P}[\mathrm{kN}]$ & $\mathrm{P}[\mathrm{kN}]$ & Dev. [\%] & $\mathrm{P}[\mathrm{kN}]$ & Dev. $[\%]$ \\
\hline PG1 & 1.0 & 560.1 & 518.0 & 505.2 & -9.8 & 499.4 & -3.6 \\
\hline PG2 & 1.0 & 662.6 & 651.8 & 624.1 & -5.8 & 626.3 & -3.9 \\
\hline PG3 & 1.0 & 680.3 & 669.2 & 646.7 & -4.9 & 647.3 & -3.3 \\
\hline PG4 & 1.5 & 523.0 & 475.5 & 465.1 & -11.1 & 443.0 & -6.8 \\
\hline PG5 & 1.5 & 582.7 & 561.0 & 523.6 & -10.1 & 525.9 & -6.2 \\
\hline PG6 & 1.5 & 609.2 & 590.9 & 571.6 & -6.2 & 572.6 & -3.1 \\
\hline PG7 & 2.0 & 517.2 & 510.1 & 463.8 & -10.3 & 469.1 & -8.0 \\
\hline PG8 & 2.0 & 537.5 & 524.8 & 479.1 & -10.9 & 487.5 & -7.1 \\
\hline \multicolumn{2}{|c|}{ Mean deviation [\%] } & & & & -8.6 & & -5.3 \\
\hline
\end{tabular}

\subsubsection{Elevated temperature}

Table 13 shows the influence of the residual stresses on the ultimate shear strength of steel plate girders subjected to elevated temperatures. It is shown that there is no substantial reduction on the ultimate loads of the analysed plate girders and, consequently, one can conclude that the residual stresses do not need to be taken into account on the numerical analysis of steel plate girders subjected to elevated temperatures. The results showed that residual stresses are not so important for the ultimate shear strength of steel plate girders exposed to fire. Tide [26] and Quiel et al. [18] affirm that a relaxation of initial residual stresses is likely to occur when a steel member is exposed to fire due to an increase in steel temperature. However, it is important bearing in mind that the evolution of the residual stresses when a profile is exposed to fire is not very well known and their influence may not be always considered appropriately in the numerical calculation [22]. 
Table 13 - Residual stresses sensitivity analysis at elevated temperature

\begin{tabular}{|c|c|c|c|c|c|c|c|}
\hline \multirow{3}{*}{ Label } & \multirow{3}{*}{$\mathrm{a} / \mathrm{hw}$} & \multicolumn{2}{|c|}{ Without Residual Stresses } & \multicolumn{4}{|c|}{ With Imperfections + Residual Stresses } \\
\hline & & $\mathrm{tw} / 10$ & EC3 & \multicolumn{2}{|c|}{$\mathrm{tw} / 10$} & \multicolumn{2}{|c|}{ EC3 } \\
\hline & & $\mathrm{P}[\mathrm{kN}]$ & $\mathrm{P}[\mathrm{kN}]$ & $\mathrm{P}[\mathrm{kN}]$ & Dev. [\%] & $\mathrm{P}[\mathrm{kN}]$ & Dev. [\%] \\
\hline PG1 & 1.0 & 349.1 & 350.4 & 348.8 & -0.1 & 350.2 & -0.1 \\
\hline PG2 & 1.0 & 409.4 & 410.7 & 409.0 & -0.1 & 409.9 & -0.2 \\
\hline PG3 & 1.0 & 441.2 & 443.0 & 440.0 & -0.3 & 441.7 & -0.3 \\
\hline PG4 & 1.5 & 290.3 & 290.5 & 289.7 & -0.2 & 290.0 & -0.2 \\
\hline PG5 & 1.5 & 337.8 & 339.6 & 337.2 & -0.2 & 338.7 & -0.3 \\
\hline PG6 & 1.5 & 390.1 & 392.1 & 389.3 & -0.2 & 390.8 & -0.3 \\
\hline PG7 & 2.0 & 278.8 & 282.0 & 276.9 & -0.7 & 280.4 & -0.6 \\
\hline PG8 & 2.0 & 294.7 & 299.5 & 292.5 & -0.7 & 297.5 & -0.7 \\
\hline \multicolumn{2}{|c|}{ Mean deviation [\%] } & & & & -0.3 & & -0.3 \\
\hline
\end{tabular}

\subsection{End supports}

In order to evaluate the influence of the end supports on the ultimate shear strength of steel plate girders, three different end configurations were considered, as presented in Figure 16. Regarding the geometric imperfections, maximum amplitude equal to $t_{w} / 10$ was considered. The residual stresses were also taken into account. In the numerical analysis, a different failure mode was observed in the plate girders with no end posts. These plate girders fail by web crippling instead of shear buckling and, as expected, the ultimate shear strength is significantly lower. Consequently, only the strength enhancement given by the rigid end post condition, in comparison to the non-rigid, is quantified in detail.

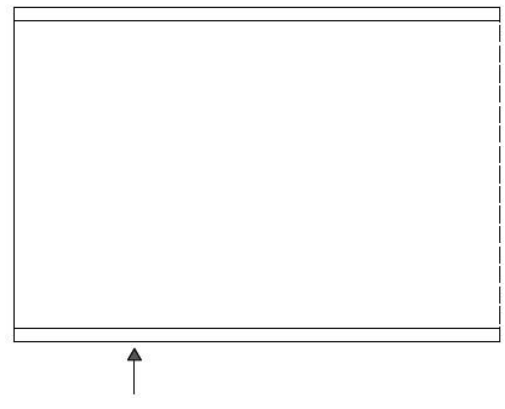

a) No end post

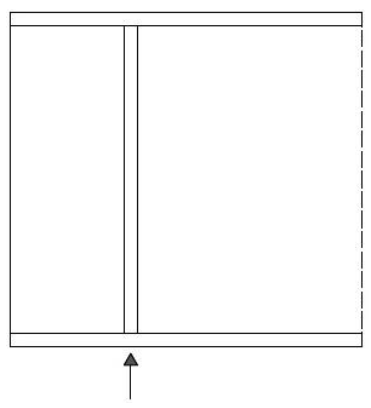

b) Non-rigid end post

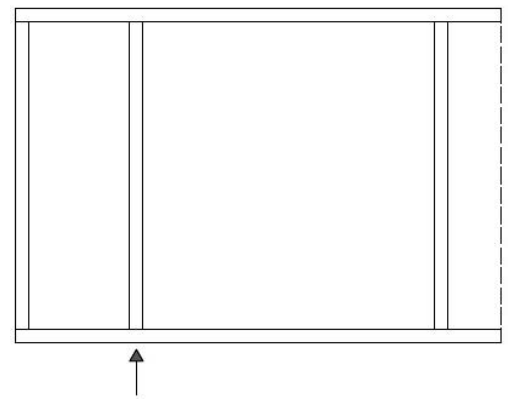

c) Rigid end post

Figure 16 - End supports 


\subsubsection{Normal temperature}

Considering the test set-up used by Lee and Yoo [9], the strength enhancement given by the rigid end post is not substantial, being the maximum $1.7 \%$, as one can see in Table 14. This was expected since the 4-panels configuration of the analysed beams (see Figure 1) requires imposes the failure occurrence in the intermediate panel, being the longitudinal force existing in the web, at the post-critical stage, anchored in the small end panels and making the rigid end post almost negligible when analysing the ultimate shear strength of this type of steel plate girders. Consequently, in order to study the real potential of the rigid end post condition, a new group of plate girders with a 2-panels configuration was considered, as presented in Figure 17. The dimensions and the material properties of the plate girders are presented in Table 15.

Table 14 - Strength enhancement at normal temperature given by the rigid end post in steel plate girders where the failure occurs in the intermediate panel

\begin{tabular}{|c|c|c|c|c|}
\hline \multirow{2}{*}{ Label } & \multirow{2}{*}{$\begin{array}{c}\mathrm{a} / \mathrm{h}_{\mathrm{w}} \\
{[-]}\end{array}$} & \multicolumn{2}{|c|}{ Ultimate load $[\mathrm{kN}]$} & \multirow{2}{*}{$\begin{array}{c}\text { Strength } \\
\text { enhancement [\%] }\end{array}$} \\
\hline & & Non-rigid end post & Rigid end post & \\
\hline PG1 & 1.00 & 505.2 & 506.1 & 0.2 \\
\hline PG2 & 1.00 & 624.1 & 631.8 & 1.2 \\
\hline PG3 & 1.00 & 646.7 & 658.0 & 1.7 \\
\hline PG4 & 1.50 & 465.1 & 465.5 & 0.1 \\
\hline PG5 & 1.50 & 523.6 & 525.5 & 0.4 \\
\hline PG6 & 1.50 & 571.6 & 579.4 & 1.4 \\
\hline PG7 & 2.00 & 463.8 & 464.3 & 0.1 \\
\hline PG8 & 2.00 & 479.1 & 480.0 & 0.2 \\
\hline
\end{tabular}




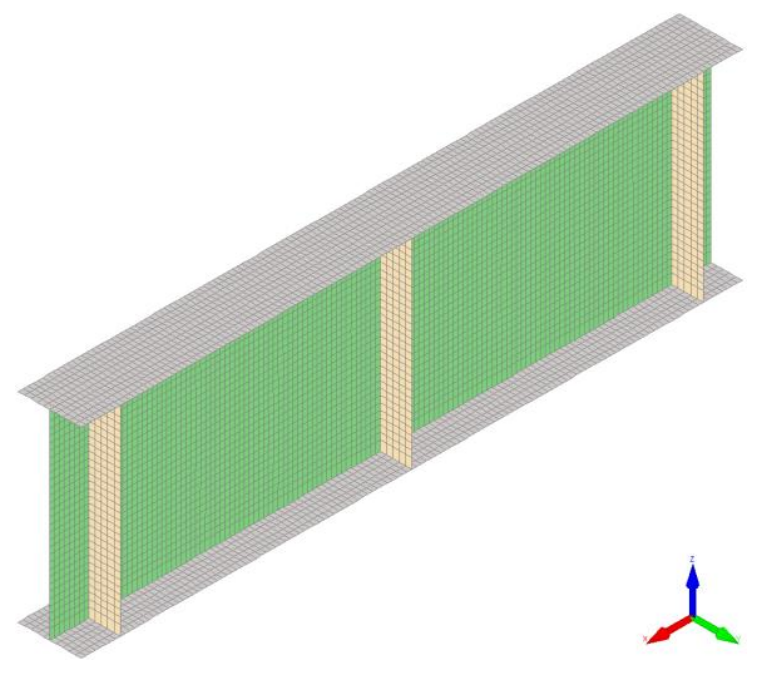

a) girders with non-rigid end posts

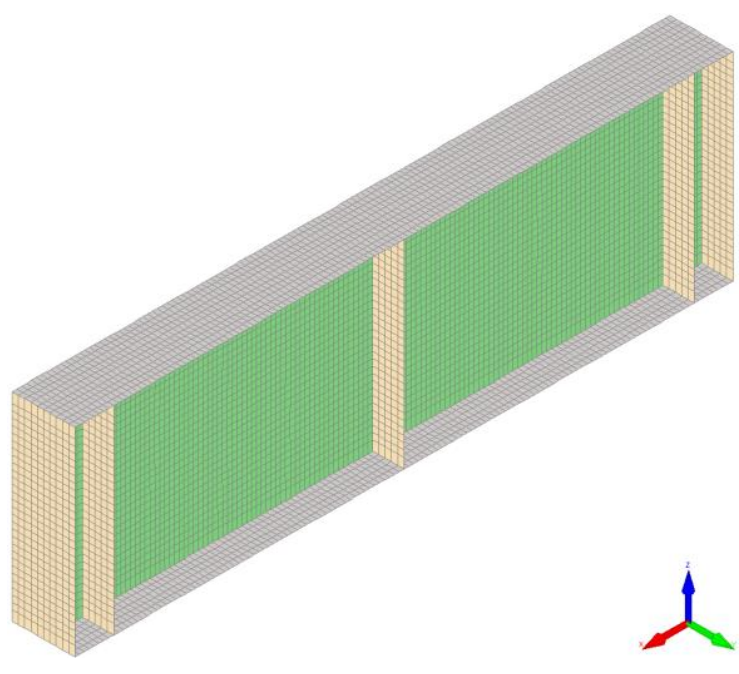

b) girders with rigid end posts

Figure 17 - Geometry of the new group of 2-panels plate girders

Table 15 - Dimensions and material properties considered for the 2-panels plate girders

\begin{tabular}{|c|ccc|cc|cc|c|c|c|c|c|c|}
\hline Label & $\begin{array}{c}\mathrm{L} \\
{[\mathrm{mm}]}\end{array}$ & $\begin{array}{c}\mathrm{a} \\
{[\mathrm{mm}]}\end{array}$ & $\begin{array}{c}\mathrm{e} \\
{[\mathrm{mm}]}\end{array}$ & $\begin{array}{c}\mathrm{h}_{\mathrm{w}} \\
{[\mathrm{mm}]}\end{array}$ & $\begin{array}{c}\mathrm{t}_{\mathrm{w}} \\
{[\mathrm{mm}]}\end{array}$ & $\begin{array}{c}\mathrm{b}_{\mathrm{f}} \\
{[\mathrm{mm}]}\end{array}$ & $\begin{array}{c}\mathrm{t}_{\mathrm{f}} \\
{[\mathrm{mm}]}\end{array}$ & $\begin{array}{c}\mathrm{t}_{\mathrm{s}} \\
{[\mathrm{mm}]}\end{array}$ & $\begin{array}{c}\mathrm{a} / \mathrm{h}_{\mathrm{w}} \\
{[-]}\end{array}$ & $\begin{array}{c}\mathrm{f}_{\mathrm{yw}} \\
{[\mathrm{MPa}]}\end{array}$ & $\begin{array}{c}\mathrm{f}_{\mathrm{yf}} \\
{[\mathrm{MPa}]}\end{array}$ & $\begin{array}{c}\mathrm{f}_{\mathrm{ys}} \\
{[\mathrm{MPa}]}\end{array}$ & $\begin{array}{c}\mathrm{E} \\
{[\mathrm{GPa}]}\end{array}$ \\
\hline PG-A10 & 800 & 400 & 80 & 400 & & 130 & & & 1.0 & & & & \\
PG-B10 & 1200 & 600 & 100 & 600 & & 200 & & & 1.0 & & & & \\
PG-A15 & 1200 & 600 & 80 & 400 & & 130 & & & & & & & \\
PG-B15 & 1800 & 900 & 100 & 600 & 3.0 & 200 & & & 1.5 & & & & \\
PG-A20 & 1600 & 800 & 80 & 400 & and & 130 & 15.0 & 10.0 & & 318.5 & 303.8 & 318.5 & 210.0 \\
PG-B20 & 2400 & 1200 & 100 & 600 & 4.0 & 200 & & & 2.0 & & & & \\
PG-A25 & 2000 & 1000 & 80 & 400 & & 130 & & & & & & & \\
PG-B25 & 3000 & 1500 & 100 & 600 & & 200 & & & 2.5 & & & & \\
\hline
\end{tabular}

The results of the numerical analyses about the influence of the rigid end post at normal temperature are presented in Table 16 for plate girders with $3 \mathrm{~mm}$ web thickness and in Table 17 for plate girders with web thickness equal to $4 \mathrm{~mm}$. Figure 18 shows the increase of strength given by the rigid end post when compared to the girders with nonrigid end posts. It is visible that the lower the aspect ratio is, the higher the increase of strength is. On the other hand, it is perceptible that the higher the web slenderness $\left(\mathrm{h}_{\mathrm{w}} / \mathrm{t}_{\mathrm{w}}\right)$ is, the more evident the increase in the ultimate shear strength given by the rigid end post is. 
Table 16 - Results of the 2-panels plate girders with web thickness of $3 \mathrm{~mm}$ at normal temperature

\begin{tabular}{|c|c|c|c|c|}
\hline \multirow{2}{*}{ Label } & \multirow{2}{*}{$\begin{array}{c}\mathrm{a} / \mathrm{h}_{\mathrm{w}} \\
{[-]}\end{array}$} & \multicolumn{2}{|c|}{ Ultimate load $[\mathrm{kN}]$} & \multirow{2}{*}{$\begin{array}{c}\text { Strength } \\
\text { enhancement }[\%]\end{array}$} \\
\hline & & Non-rigid end post & Rigid end post & \\
\hline PGA-10 & 1.0 & 357.8 & 380.6 & 6.4 \\
\hline PGB-10 & 1.0 & 428.7 & 474.7 & 10.7 \\
\hline PGA-15 & 1.5 & 304.0 & 314.1 & 3.3 \\
\hline PGB-15 & 1.5 & 368.1 & 389.1 & 5.7 \\
\hline PGA-20 & 2.0 & 289.6 & 293.2 & 1.2 \\
\hline PGB-20 & 2.0 & 333.8 & 346.2 & 3.7 \\
\hline PGA-25 & 2.5 & 273.9 & 274.6 & 0.3 \\
\hline PGB-25 & 2.5 & 309.3 & 317.4 & 2.6 \\
\hline
\end{tabular}

Table 17 - Results of the 2-panels plate girders with web thickness of $4 \mathrm{~mm}$ at normal temperature

\begin{tabular}{|c|c|c|c|c|}
\hline \multirow{2}{*}{ Label } & \multirow{2}{*}{$\begin{array}{c}\mathrm{a} / \mathrm{h}_{\mathrm{w}} \\
{[-]}\end{array}$} & \multicolumn{2}{|c|}{ Ultimate load $[\mathrm{kN}]$} & \multirow{2}{*}{$\begin{array}{c}\text { Strength } \\
\text { enhancement }[\%]\end{array}$} \\
\hline & & Non-rigid end post & Rigid end post & \\
\hline PGA-10 & 1.0 & 532.0 & 534.4 & 0.5 \\
\hline PGB-10 & 1.0 & 617.2 & 655.5 & 6.2 \\
\hline PGA-15 & 1.5 & 478.9 & 480.1 & 0.3 \\
\hline PGB-15 & 1.5 & 534.9 & 552.9 & 3.4 \\
\hline PGA-20 & 2.0 & 460.4 & 462.1 & 0.4 \\
\hline PGB-20 & 2.0 & 517.1 & 527.4 & 2.0 \\
\hline PGA-25 & 2.5 & 442.9 & 442.7 & 0.0 \\
\hline PGB-25 & 2.5 & 490.6 & 493.1 & 0.5 \\
\hline
\end{tabular}

$20^{\circ} \mathrm{C}$

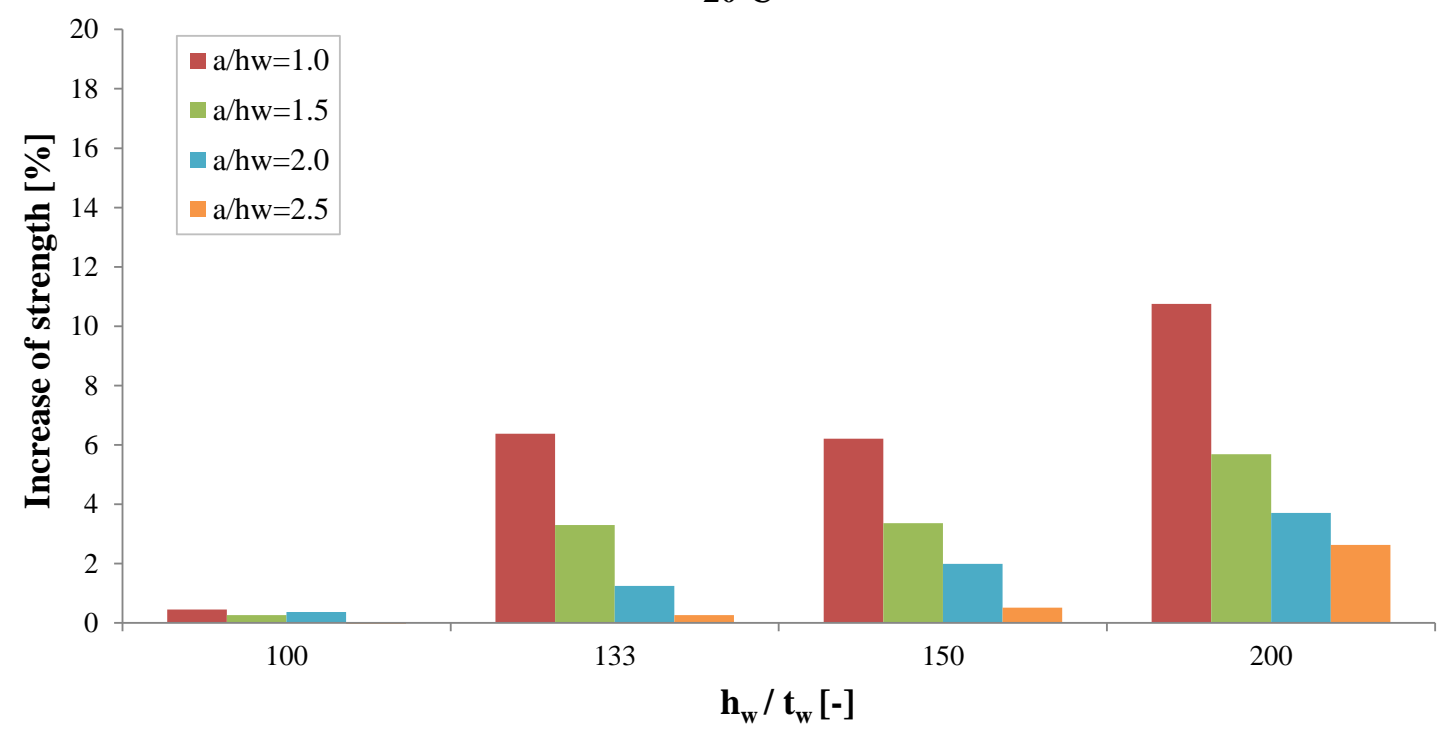

Figure 18 - Strength enhancement at normal temperature 


\subsubsection{Elevated temperature}

The increase of strength given by the condition of rigid end post is illustrated in Figure 19. The rigid end post is important to anchor the membrane stresses due to tension field action that occurs after buckling. As observed at normal temperature, with higher the web slenderness and lower the aspect ratio, the larger the strength enhancement given by the rigid end post is. For the same web depth, the lower the web thickness is, the larger is the susceptibility of the web panel to the occurrence of shear buckling. Consequently, it is perceptible by comparing the results presented in Tables 18 and 19 that the field of action of the rigid end post increases with the growth of the girder susceptibility to shear buckling, helping to obtain a higher post-buckling resistance.

Furthermore, comparing Figure 18 and Figure 19, one can observe that the condition of rigid end post is more relevant in fire situation (increase of strength up to 19.8\%) than at normal temperature (increase of strength up to 10.7\%), which suggests that the use of rigid end posts should be encouraged for fire design.

Table 18 - Results of the 2-panels plate girders with web thickness of $3 \mathrm{~mm}$ at elevated temperature

\begin{tabular}{|c|c|cc|c|}
\hline \multirow{2}{*}{ Label } & $\mathrm{a} / \mathrm{h}_{\mathrm{w}}$ & \multicolumn{2}{|c|}{ Ultimate load $[\mathrm{kN}]$} & $\begin{array}{c}\text { Strength } \\
{[-]}\end{array}$ \\
& Non-rigid end post & Rigid end post & enhancement [\%] \\
\hline PGA-10 & 1.0 & 243.5 & 279.2 & 14.6 \\
PGB-10 & 1.0 & 286.5 & 343.1 & 19.8 \\
PGA-15 & 1.5 & 202.0 & 219.1 & 8.4 \\
PGB-15 & 1.5 & 237.6 & 266.1 & 12.0 \\
PGA-20 & 2.0 & 179.3 & 189.2 & 5.5 \\
PGB-20 & 2.0 & 208.9 & 226.8 & 8.6 \\
PGA-25 & 2.5 & 163.5 & 167.2 & 2.2 \\
PGB-25 & 2.5 & 189.3 & 198.7 & 5.0 \\
\hline
\end{tabular}


Table 19 - Results of the 2-panels plate girders with web thickness of $4 \mathrm{~mm}$ at elevated temperature

\begin{tabular}{|c|c|c|c|c|}
\hline \multirow{2}{*}{ Label } & \multirow{2}{*}{$\begin{array}{c}\mathrm{a} / \mathrm{h}_{\mathrm{w}} \\
{[-]}\end{array}$} & \multicolumn{2}{|c|}{ Ultimate load $[\mathrm{kN}]$} & \multirow{2}{*}{$\begin{array}{c}\text { Strength } \\
\text { enhancement }[\%]\end{array}$} \\
\hline & & Non-rigid end post & Rigid end post & \\
\hline PGA-10 & 1.0 & 343.0 & 370.7 & 8.1 \\
\hline PGB-10 & 1.0 & 397.2 & 453.6 & 14.2 \\
\hline PGA-15 & 1.5 & 289.3 & 302.0 & 4.4 \\
\hline PGB-15 & 1.5 & 338.1 & 364.6 & 7.8 \\
\hline PGA-20 & 2.0 & 267.4 & 274.0 & 2.5 \\
\hline PGB-20 & 2.0 & 309.9 & 323.9 & 4.5 \\
\hline PGA-25 & 2.5 & 249.8 & 252.2 & 1.0 \\
\hline PGB-25 & 2.5 & 287.1 & 293.9 & 2.4 \\
\hline
\end{tabular}

$500^{\circ} \mathrm{C}$

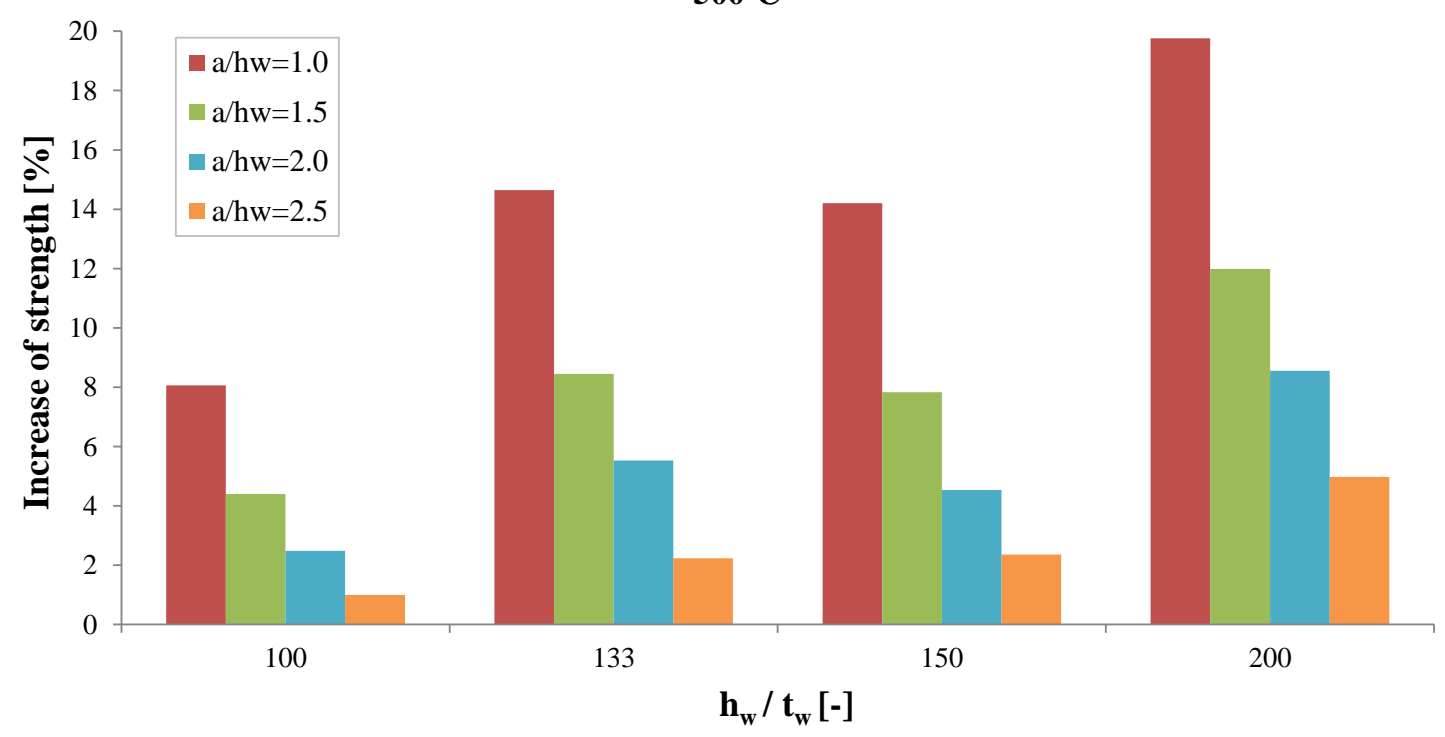

Figure 19 - Strength enhancement at elevated temperature

\section{Conclusions}

In this study a solid numerical model capable of predicting the behaviour of steel plate girders at both normal and elevated temperatures was developed. For this purpose, a total of 26 experimental tests were numerically modelled using the software SAFIR $[13,14]$. These experiments involved plate girders tested at both normal and elevated temperatures. Comparisons between the numerical and the experimental results were 
performed. Furthermore, in the cases where there is available data, the numerical results provided by SAFIR were also compared to the results of the numerical modelling performed by the authors of the experimental tests.

It was shown that the numerical model developed in SAFIR provides a good approximation to the actual behaviour of steel plate girders at both normal and elevated temperatures. Concerning the plate girders tested at normal temperature, a good approximation between the experimental and numerical results was obtained, with the mean deviation generally conservative equal to $3.8 \%$. Regarding the numerical results of the plate girders tested at elevated temperatures, the mean deviation was $8.4 \%$, conservative in most of the cases.

About the influence of the initial imperfections on the bearing capacity of steel plate girders affected by shear buckling, it was concluded that the geometric imperfections must be always taken into account in the numerical modelling of steel plate girders with aspect ratios between 1.0 and 2.0, at both normal and elevated temperature. As shown in other studies $[17,18]$, it was found that $\mathrm{t}_{\mathrm{w}} / 10$ is an appropriate value for the modelling of experimental tests on steel plate girders. Moreover, one could observe that, for the analysed plate girders, the residual stresses influence the ultimate shear strength of steel plate girders at normal temperature but its influence at elevated temperature is not so relevant.

Finally, for the analysed plate girders with aspect ratios between 1.0 and 2.0, it was observed that the condition of rigid end post is more effective in fire situation than at normal temperature. Furthermore, for this range of plate girders, it was noticed that the lower the aspect ratio is and the higher the web slenderness is, the higher the strength enhancement is, at both normal and elevated temperatures. 


\section{Acknowledgments}

This research work was partially funded by the Portuguese Government through the FCT (Foundation for Science and Technology) under the PhD grant SFRH/BD/85563/2012 (POPH/FSE funding) awarded to the first author. The authors would also like to thank to Professor Sung Lee for the data and valuable information provided which was helpful to the development of this work.

\section{Notation}

$\begin{array}{ll}\text { a } & \text { transverse stiffeners spacing } \\ b_{f} & \text { flange width } \\ b_{l s} & \text { longitudinal stiffener width } \\ \text { e } & \text { transverse stiffeners spacing of the rigid end post } \\ \text { E } & \text { Young's modulus } \\ f_{y f} & \text { flange yield strength } \\ f_{y w} & \text { web yield strength } \\ h_{w} & \text { web depth } \\ L & \text { girder length } \\ P & \text { ultimate load } \\ \text { PG } & \text { plate girder } \\ t_{w} & \text { web thickness } \\ t_{f} & \text { flange thickness } \\ t_{s} & \text { transverse stiffeners thickness } \\ t_{l s} & \text { longitudinal stiffeners thickness }\end{array}$




\section{References}

[1] Höglund T. Shear buckling resistance of steel and aluminium plate girders. ThinWalled Structures, 1997; 29(1-4): 13-30. doi:10.1016/S0263-8231(97)00012-8

[2] CEN. Eurocode 3: Design of Steel Structures. Part 1-5: Plated Structural Elements, Brussels, 2006.

[3] Lee SC, Davidson JS, Yoo CH. Shear buckling coefficients of plate girder web panels. Computers and Structures, 1996; 59(5): 789-95. doi:10.1016/00457949(95)00325-8

[4] Lee SC, Yoo CH. Strength of plate girder web panels under pure shear. Journal $\begin{array}{lllll}\text { of } & \text { Structural } & \text { Engineering, } & 1998 ; & 124(2):\end{array}$ http://dx.doi.org/10.1061/(ASCE)0733-9445(1998)124:2(184)

[5] Lee SC, Lee DS, Yoo CH. Ultimate shear strength of long web panels. Journal of Constructional Steel Research, 2008; 64(12): 1357-65. doi:10.1016/j.jcsr.2008.01.023

[6] Garlock M, Glassman J. Elevated temperature evaluation of an existing steel web shear buckling analytical model. Journal of Constructional Steel Research, 2014; 101: 395-06. doi:10.1016/j.jcsr.2014.05.021

[7] Kodur VK, Naser MZ. Effect of shear on fire response of steel beams. Journal of Constructional Steel Research, 2014; 97: 48-58. doi:10.1016/j.jcsr.2014.01.018

[8] Reis A, Lopes N, Real E, Vila Real P. Stainless steel plate girders subjected to shear buckling at normal and elevated temperatures", Fire Technology, 1-29, 2016. doi:10.1007/s10694-016-0602-6. 
[9] Lee SC, Yoo CH. Experimental study on ultimate shear strength of web panels. Journal of $\quad$ Structural Engineering, $\quad 1999 ; \quad 125: \quad 838-46$. http://dx.doi.org/10.1061/(ASCE)0733-9445(1999)125:8(838)

[10] Gomes C, Cruz P, Silva L. Experimental evaluation of shear behaviour of slender steel beams (in Portuguese). Engineering Civil Magazine of University of Minho, no. 7, 2000.

[11] Vimonsatit V, Tan KH, Qian ZH. Testing of plate girder web panel loaded in shear at elevated temperature. Journal of Structural Engineering, 2007; 133(6): 815-24. http://dx.doi.org/10.1061/(ASCE)0733-9445(2007)133:6(815)

[12] Vimonsatit V, Tan KH, Ting SK. Shear strength of plate girder web panel at elevated temperature. Journal of Constructional Steel Research, 2007; 63(11): 1442-51. doi:10.1016/j.jcsr.2007.01.002

[13] Franssen JM. SAFIR, a thermal/structural program modelling structures under fire. Engineering Journal, 2005; 43(3): 143-58. http://hdl.handle.net/2268/2928

[14] Franssen JM. User's manual for SAFIR - A computer program for analysis of structures subjected to fire: Department ArGEnCO. University of Liége, 2011.

[15] CAST3M. CAST3M is a research FEM environment; its development is sponsored by the French Atomic Energy Commission, 2012. <http://wwwcast3m.cea.fr/>.

[16] Couto C, Vila Real P, Lopes N. RUBY, an interface software for running a buckling analysis of SAFIR models using Cast3M, University of Aveiro, 2013. 
[17] Hancock GJ. Nonlinear analysis of thin sections in compression. Journal of the Structural Division, 1981; 107(3): 455-71.

[18] Quiel S, Garlock M. Calculating the buckling strength of steel plates exposed to fire. Thin-Walled Structures, 2010; 48: 684-95. doi:10.1016/j.tws.2010.04.001

[19] CEN. Eurocode 3: Design of Steel Structures. Part 1-2: General rules Structural fire design, Brussels, 2005.

[20] MSC - MARC user's guide. MSC Software Corporation, 2001.

[21] CEN. EN 1090-2:2008+A1, Execution of steel structures and aluminium structures - Part 2: Technical requirements for steel structures, 2011.

[22] Franssen JM. Residual stresses in steel profiles submitted to the fire: an analogy. Proceedings of $3^{\text {rd }}$ CIB/W14 Workshop "Modelling". TNO Building and Construction Research, 1993.

[23] Lopes N, Vila Real P, Simões da Silva L, Franssen JM. Numerical modelling of thin-walled stainless steel structural elements in case of fire. Fire Technology, 2010; 46(1): 91-108. doi:10.1007/s10694-009-0084-x

[24] ECCS. Manual on stability of steel structures. Publication no. 22. ECCS Technical Committee 8 - Structural Stability, 1976.

[25] ECCS. Ultimate limit state calculation of sway frames with rigid joints. Publication no. 33. ECCS - Technical Committee 8 - Structural Stability, Technical Working Group 8.2 - System, 1984.

[26] Tide RHR. Integrity of structural steel after exposure to fire. AISC Engineering Journal, 1998; 35: 26-38. 